\title{
Fluid geochemical transect in the Northern Apennines (central-northern Italy): fluid genesis and migration and tectonic implications
}

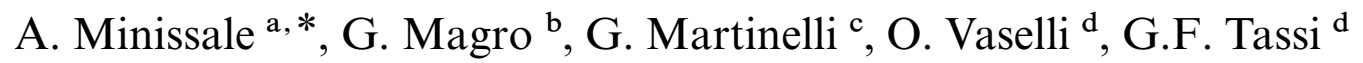 \\ ${ }^{a}$ CNR-Study Center for Minerogenesis and Applied Geochemistry, Via G. La Pira 4, 50121 Florence, Italy \\ ${ }^{\mathrm{b}}$ CNR-Institute for Geochronology and Isotope Geochemistry, Via C. Maffi 36, 56100 Pisa, Italy \\ ${ }^{\mathrm{c}}$ Emilia-Romagna Region, Cartography and Geology Office, V. le A. Silvani 4/3, 40122 Bologna, Italy \\ ${ }^{\mathrm{d}}$ Department of Earth Science, University of Florence, Via G. La Pira 4, 50121 Florence, Italy
}

Received 4 May 1999; accepted for publication 20 January 2000

\begin{abstract}
Chemical and isotopic characteristics of natural gas and thermal water discharges from the western back-arc Tyrrhenian Sea across the Apennine thrust-belt to the Po Valley and Adriatic coast foredeep basins in the Northern Apennines (central-northern Italy) reveal a large-scale fluid motion in the upper crust, both vertically and horizontally. On the basis of gas compositions, two different domains of rising fluids have been distinguished: (1) $\mathrm{CO}_{2}$-rich, He-poor, ${ }^{3} \mathrm{He} /{ }^{4} \mathrm{He}$-high domain in the western peri-Tyrrhenian extensional sector; (2) $\mathrm{CH}_{4}$-rich, He-rich, ${ }^{3} \mathrm{He} /{ }^{4} \mathrm{He}-$ low domain in the eastern Adriatic compressional sector. Such gases, rising from various depths, are crossed by a huge lateral $\mathrm{N}_{2}$-rich water flow, in the peri-Tyrrhenian sector, of $\mathrm{Ca}-\mathrm{SO}_{4}\left(\mathrm{HCO}_{3}\right)$ meteoric-derived waters that move in a regional wide aquifer hosted in a quite thick Mesozoic carbonate series.

Morphologically, the $\mathrm{CO}_{2}$ vents consist of mud basins with high gas-rate emission, where the rising fluids move upwards through diatremes. On the other hand, $\mathrm{CH}_{4}$ emissions seep out from typical mud volcanoes with a reduced gas flow-rate, where the fluid motion is likely related to saline diapir extrusions, and the methane is mostly carried to the surface by the associated mud. The two rising mechanisms described locate southwest and northeast of the Apennine watershed respectively.

From a seismic point of view the $\mathrm{CH}_{4}$ domain in the thrust-belt and foredeep areas is characterized by a large number of earthquakes, indirectly pointing to a different rheological behavior of the terrains with respect to the more internal peri-Tyrrhenian area. Owing to the quite high thermal gradient of the latter, the boundary of the brittleductile crust in the peri-Tyrrhenian sector can be located at a $<10 \mathrm{~km}$ shallow depth.

Although the presence of several post-orogenic basins would suggest widespread extensional tectonics in all areas west of the Apennine watershed, those located in the easternmost part display gas vents with typical crustal ${ }^{3} \mathrm{He} /{ }^{4} \mathrm{He}$ ratios. As this ratio is very sensitive to deep fluids rising from the mantle, we hypothesize that such basins at the foot of the Apennines are not due to tensive stress, as suggested by their morphological shape. They are piggy-back (thrust-top) basins developed and evolved in a still acting compressive tectonic regime. (C) 2000 Elsevier Science B.V. All rights reserved.
\end{abstract}

Keywords: gases; helium gas; isotope geochemistry; northern Apennines; thermal waters

\footnotetext{
* Corresponding author. Fax: + 39-55-284-571.

E-mail address: minissa@csmga.fi.cnr.it (A. Minissale)
}

0040-1951/00/\$ - see front matter (C) 2000 Elsevier Science B.V. All rights reserved. 


\section{Introduction}

Fluids in the crust are important in driving deep and shallow seismic, tectonic, petrogenetic and minerogenetic processes. Their circulation is particularly active at plate boundaries, where subduction of lithospheric slabs and associated pore fluids, and rising of mantle material causes shallow thermal perturbations with consequent increase of fluid motion in the shallow crust (Barnes et al., 1978; Oliver, 1986, 1992; Reynolds and Lister, 1987; Sverjensky and Garven, 1992).

Deep juvenile, metamorphic and geothermal vertical-moving fluids mix with lateral gradients in (water table) topographically driven meteoricderived fluids, producing water-rock interaction processes that lead to several types of fluid discharge at the surface. Such mechanisms are investigated in a complex tectonic environment such as the Northern Apennines.

The Northern Apennines is a typical arcuated compressional system formed after the Cenozoic collision between the Corso-Sardinian block and the westwards subducting Adriatic plate (Boccaletti and Guazzone, 1974). Consequent eastwards folding and thrusting of several internal west-deposited nappes, one onto an other, caused the formation of areas of back-arc in the Tyrrhenian Sea, thrust-belt in the main Apennines and foredeep-basins in the Po Valley and the Adriatic Sea (Fig. 1) (Royden et al., 1987).

Adjoining areas along the Tyrrhenian coast are characterized by the occurrence of thermal anomalies (Mouton, 1969), geothermal fields (Carella et al., 1985), Plio-Quaternary volcanism (Peccerillo and Manetti, 1985), ore deposition (Tanelli, 1983) and active $\mathrm{CO}_{2}$ degassing (Chiodini et al., 1995; Minissale et al., 1997a). The Po Valley and the Adriatic Sea are mostly affected by the presence of fast sedimentation foredeep-basins with associated hydrocarbon reservoirs (Mattavelli et al., 1983; Mattavelli and Novelli 1987).

The two areas, located on opposite sides of the main Apennine thrust-belt, from a fluid chemistry standpoint, have often been dealt with separately: one pertaining to the field of petroleum geologists and the other to the geothermal and mineral prospectors. In this paper we present new chemical and isotopic data on the natural gas emissions and associated waters in the thrust-belt and foredeep methane domains, discuss sources and evolution of the internal and external types of gas and relationships between fluids and present active tectonics. Finally, the significance of a quasi-continuous permeable horizon hosted in Mesozoic limestone formations, acting as a sink for both vertical and lateral fluid motions on the crustalscale hydrogeology of the Northern Apennines, is investigated.

\section{Geological background}

The building up of the compressional Apenninic system (Fig. 1) started in the Cretaceous with the main compressional phase, leading to the present structure, occurring in the Miocene. Tortonian eastwards obduction of ophiolite-bearing flyschoid units deposited in the Ligurian-Piedmont Ocean (Ligurian Units) above more carbonate sequences (Tuscan-Umbrian Unit) was followed by the eastwards thrusting of both of them above autochthonous foredeep pelagic units (Umbro-Romagnan and Marchean-Adriatic Units) (Abbate et al., 1970; Kligfield, 1979). Eastward migration of the deformational front towards the Adriatic Sea was driven by the counterclockwise rotation of the Corso-Sardinian microplate and westwards subduction of the Adriatic lithospheric crust, and was accompanied by lithospheric extension over previously compressive domains in the Tyrrhenian coastal areas (Malinverno and Ryan, 1986). Extensive tectonics related to the opening of the Tyrrhenian basin caused several deformational events, migrating eastward in time, such as:

(1) melting and rising of crustal and mantle magmas (Serri, 1990);

(2) establishment of shallow thermal anomalies;

(3) formation of several NW-SE (Apenninic) trending intramontane and marine basins in the inner sector of the chain (Boccaletti and Sani, 1998).

A simplified stratigraphy of the area studied discerned from the top is as follows:

(1) post-orogenic continental and marine MioQuaternary sediments filling the several basins 


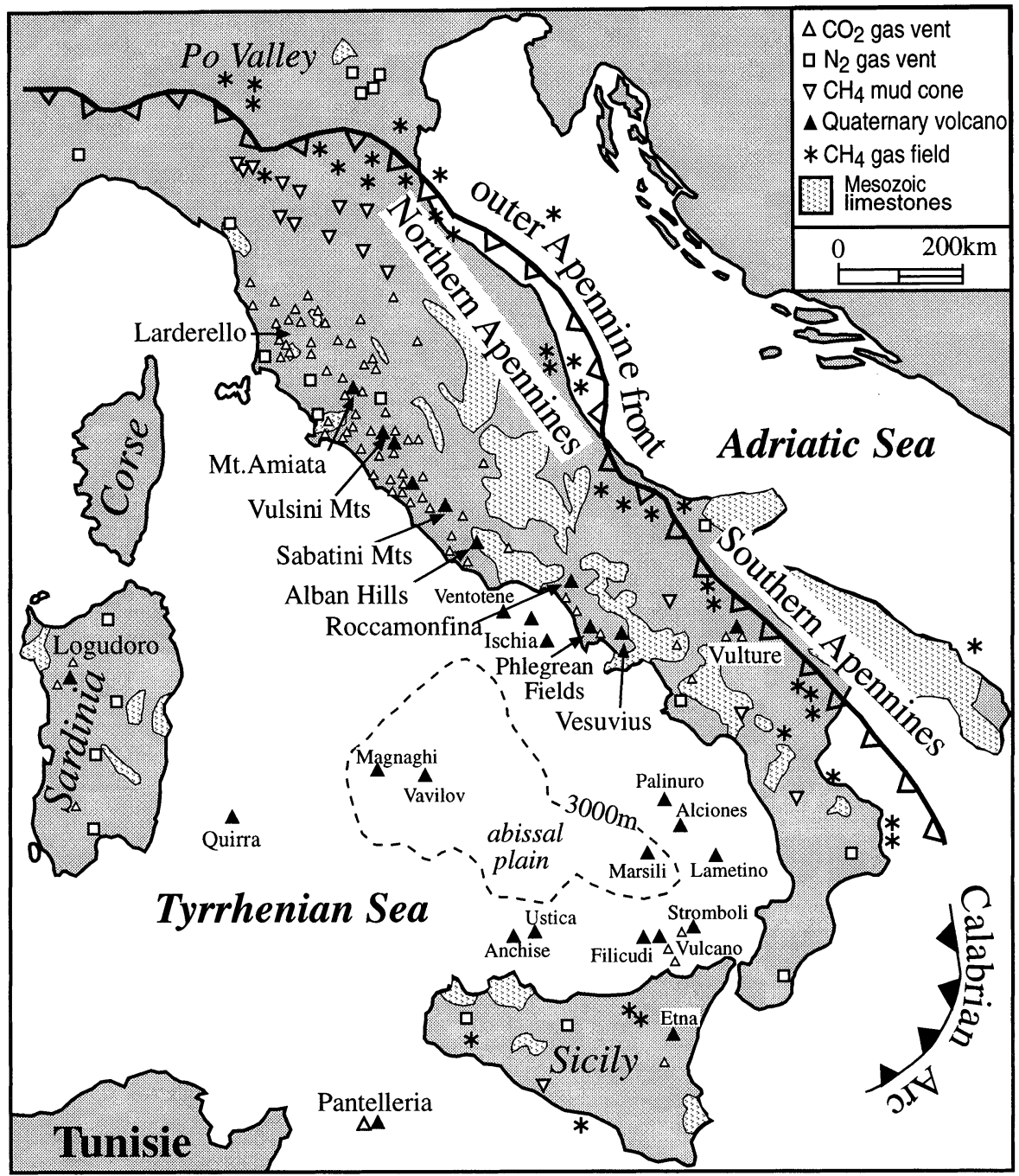

Fig. 1. Schematic map of Italy with Quaternary volcanoes, geothermal fields, gas vents, Mesozoic carbonate outcrops and thrusting fronts.

along the Tyrrhenian coast and the foredeep Adriatic areas (Po Valley);

(2) syn-orogenic turbidites deriving from the weathering of the flysch sequences;

(3) poorly permeable allochthonous CretaceousEocene flysch units (Ligurids) discontinuously outcropping from the Tyrrhenian to the Adriatic coasts;

(4) highly permeable allochthonous Mesozoic limestones covered by impermeable Cretaceous shales and thick permeable Oligo-Miocene turbidites (Tuscanids); and

(5) Paleozoic schists, micaschists and gneisses belonging to the Tuscan crystalline basement, whose limited outcrops are confined to the periTyrrhenian sector of Italy.

Small but significant outcrops of both intrusive and effusive magmatics (4.9-2.2 Ma) of crustal and mantle signature are present in the coastal Tyrrhenian areas (Serri, 1990), or have been 
crossed by wells in the Larderello-Travale geothermal area (Manzella et al., 1998). This inner sector is also characterized by a structural feature ('serie ridotta') that brought the Ligurian units above either the lowermost formation of the Tuscan sequence ('Burano' evaporites) or directly above the crystalline basement.

The older westernmost Neogene post-orogenic basins host a complex sequence made up of Miocene continental sediments, Messinian evaporites and thick Pliocene marine clay sequences. On the contrary, the more recent easternmost basins (such as the Mugello and Casentino basins in Fig. 2) are much younger and filled only by Quaternary intramontane continental sediments.

\section{Fluids discharged at surface}

Apart from the Larderello-Travale area, hosting the longest living geothermal field in the world (Minissale, 1991a), with its spectacular steam vents

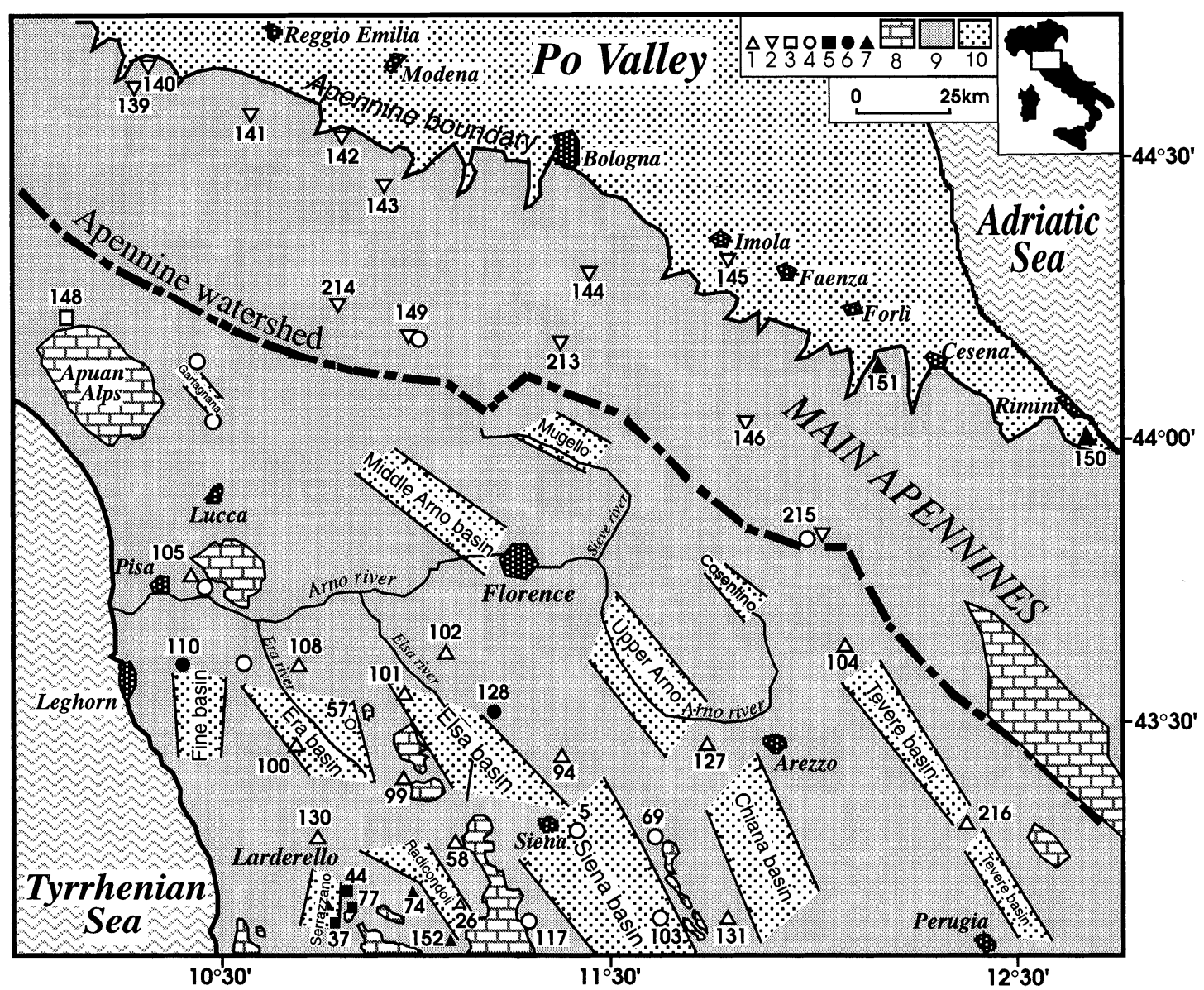

Fig. 2. Schematic map of the Northern Apennines and location of gas vents and associated waters. (1) Dry $\mathrm{CO}_{2}$ vents; (2) $\mathrm{CH}_{4}$-rich mud volcanoes; (3) thermal springs with associated $\mathrm{N}_{2}$-rich gas; (4) thermal springs emerging at the boundaries of the Mesozoic carbonate series with a $\mathrm{CO}_{2}$-rich gas phase; (5) steam condensates sampled in the Larderello geothermal field; (6) cold springs with a $\mathrm{CO}_{2}$-rich associated gas phase; (7) cold or thermal springs where ${ }^{3} \mathrm{He} /{ }^{4} \mathrm{He}$ ratio has been determined from stripped gas; (8) outcrops of the Mesozoic limestones or crystalline basement; (9) Apennine formations lying above the Mesozoic limestones or the crystalline basement where limestones are missing; (10) sediments of the Po Valley. The figure also shows the Apennine watershed, as well as the main post-orogenic (or piggy-back) basins formed during and after the main Tortonian tectonic phase. 
and mud boiling pools, the area located south of Florence and the Arno river in Fig. 2 (southern Tuscany) displays a large number of thermal springs (Bencini et al., 1977; Minissale and Duchi, 1988) and $\mathrm{CO}_{2}$ gas emissions (Minissale et al., 1997a). Thermal springs are generally located at the boundaries of the Mesozoic carbonate formation outcrops in the Tuscan series, representing the main regional aquifer. They are generally $\mathrm{Ca}-\mathrm{SO}_{4}$ in composition due to the presence of tectonically laminated (up to $600 \mathrm{~m}$ ) anhydrite layers ('Burano' evaporites) between the carbonate series and the crystalline basement (Trevisan, 1951). When they are associated with $\mathrm{CO}_{2}$ emissions (close to the geothermal areas), large travertine deposition may occur. More often the $\mathrm{CO}_{2}$ emissions are dry and/or associated with cold springs and rainy waters, vigorously bubbling in gas pools formed by the alteration of soil around the orifices (Duchi and Minissale, 1995).

North of the Arno river (Fig. 2) $\mathrm{CO}_{2}$ emissions are lacking. There are still thermal springs (Arrigoni et al., 1982; Bencini and Duchi, 1981), some of which still emerge close to the carbonate outcrops (east of Pisa and the Garfagnana basin in Fig. 2), but the associated gas phase is chemically characterized by either gently bubbling $\mathrm{N}_{2}$ or $\mathrm{CH}_{4}$. Dry methane gas emissions along the Apennine watershed, some of which are exploited for local gas stations, and mud volcanoes along the boundary area between the Apennine outcrops and the Po Valley sediments (Fig. 2) are the main natural features of this area. Mud volcanoes are typical manifestations of accretionary complexes along continental margins, where compression favors fluid expulsion from the shallower parts of the crust (Le Pichon et al., 1990; Davisson et al., 1994).

\section{Sampling and analytical procedures}

The location of gas and water samples is reported in Fig. 2. The emergence temperature, $\mathrm{pH}$ and $\mathrm{HCO}_{3}$ concentration of spring waters and mud volcanoes were measured in the field, whereas the other components were determined in the laboratory using procedures described in Duchi et al. (1986). The gas sampling was carried out following the procedure of Giggenbach (1975) by means of two $100 \mathrm{~cm}^{3}$ pre-evacuated glass tubes, one containing $50 \mathrm{~cm}^{3}$ of $4 \mathrm{~N} \mathrm{NaOH}$ to concentrate the non-reactive components. The in situ radon measurement was done using an EDA RDA-200 portable detector according to the Washington and Rose (1992) counting method for fission tracks.

Gas components were determined in the laboratory by gas-chromatography using a thermal conductivity detector for $\mathrm{CO}_{2}, \mathrm{~N}_{2}, \mathrm{O}_{2}, \mathrm{H}_{2} \mathrm{~S}, \mathrm{He}, \mathrm{Ar}$ and $\mathrm{H}_{2}$ and a flame ionization detector for $\mathrm{CH}_{4}$ and CO. Air was used as a standard. Analytical precision was $<1 \%$ for major gas species and $<5 \%$ for minor and trace compounds.

The ${ }^{4} \mathrm{He},{ }^{20} \mathrm{Ne}$ and ${ }^{22} \mathrm{Ne}$ and, after separation, ${ }^{40} \mathrm{Ar}$ and ${ }^{36} \mathrm{Ar}$ were measured in a static way using a Spectrolab 200 VG-Micromass quadrupole mass spectrometer (Magro and Pennisi, 1991). ${ }^{3} \mathrm{He} /{ }^{4} \mathrm{He}$ ratios were determined with a Map 215-50 magnetic mass spectrometer, equipped with an ion counting device. Resolution was close to $600 \mathrm{amu}$ for $\mathrm{HD}-{ }^{3} \mathrm{He}$ at $5 \%$ of the peak. Pipetted atmospheric noble gases were used to estimate the sensitivity of the two mass-spectrometers. No blank corrections were applied to the He measurements owing to its concentration, which was generally several orders of magnitude higher than that of the extraction line and the instrumental static background. Overall analytical errors were estimated to be less than $10 \%$ for abundances and less than $5 \%$ for ratios.

After separating $\mathrm{CO}_{2}$ and $\mathrm{CH}_{4}$ in the gas phase in a vacuum line using standard procedures, ${ }^{13} \mathrm{C} /{ }^{12} \mathrm{C}$ isotopic ratios in $\mathrm{CO}_{2}$ and $\mathrm{CH}_{4}$, in samples where their concentration was $>1 \%$, were analyzed by using a Finningan MAT 251 mass spectrometer. Several internationally accepted standards (such as Iceland spar) were used, with a typical error of $\pm 0.05 \%$ o (PDB).

\section{Chemistry of waters}

All water samples considered in the present survey are characterized by having an associated gas phase. Chemical and isotopic analyses of ther- 
Table 1

Chemical composition $(\mathrm{mg} / \mathrm{kg}$ ) of waters from the Northern Apennines

\begin{tabular}{|c|c|c|c|c|c|c|c|c|c|c|c|c|c|c|c|c|c|}
\hline No. & Sampling site & Type $^{\mathrm{b}}$ & $\begin{array}{l}T \\
\left({ }^{\circ} \mathrm{C}\right)\end{array}$ & $\mathrm{pH}$ & $\mathrm{Na}$ & $\mathrm{K}$ & $\mathrm{Ca}$ & $\mathrm{Mg}$ & $\mathrm{HCO}_{3}$ & $\mathrm{SO}_{4}$ & $\mathrm{Cl}$ & $\mathrm{SiO}_{2}$ & $\mathrm{H}_{3} \mathrm{BO}_{3}$ & $\mathrm{NH}_{4}$ & $\mathrm{Li}$ & $\delta^{18} \mathrm{O}$ & $\delta \mathrm{D}$ \\
\hline 5 & Acqua Borra ${ }^{c}$ & ts & 36 & 6.40 & 3864 & 277.0 & 628 & 142 & 3560 & 1075 & 5183 & 30 & 340.0 & 37.8 & 12.30 & -5.4 & -40.1 \\
\hline 57 & Palagio $^{\mathrm{d}}$ & ts & 22 & 6.30 & 97 & 7.0 & 480 & 814 & 3965 & 1152 & 50 & 90 & 4.4 & 1.6 & 0.31 & $\mathrm{nd}^{\mathrm{a}}$ & nd \\
\hline 69 & Bagni Freddi ${ }^{\mathrm{c}}$ & ts & 27 & 6.29 & 276 & 38.0 & 638 & 180 & 2178 & 830 & 248 & 25 & 55.0 & 1.7 & 0.73 & -7.5 & -44.1 \\
\hline 103 & S. G. d'Asso ${ }^{c}$ & ts & 27 & 6.10 & 74 & 16.0 & 700 & 204 & 1220 & 1584 & 78 & 16 & 7.3 & 0.2 & 0.20 & -7.7 & nd \\
\hline 117 & Doccio $^{c}$ & ts & 34 & 5.85 & 460 & 37.0 & 680 & 132 & 976 & 1680 & 674 & 35 & 46.0 & 0.2 & 2.60 & -6.0 & -40.8 \\
\hline 215 & Bagno Romagna ${ }^{e}$ & ts & 43 & 8.50 & 300 & 4.7 & 3 & 0.8 & 793 & 5.0 & 27 & 24 & nd & nd & nd & -8.6 & -54.3 \\
\hline 149 & Porretta $^{\mathrm{f}}$ & ts & 35 & 7.35 & 1909 & 70.0 & 26 & 8.2 & 854 & 2.0 & 2627 & 29 & 161.0 & nd & 3.70 & -7.9 & -51.1 \\
\hline 148 & Equi Terme $^{\mathrm{d}}$ & ts & 24 & 7.10 & 1196 & 27.0 & 280 & 63 & 244 & 624 & 1952 & 16 & 4.6 & nd & 0.70 & -7.5 & -49.0 \\
\hline 37 & Lago $^{g}$ & sv & 95 & 8.60 & 1 & 1.1 & $<0.2$ & $<0.1$ & 207 & $<0.5$ & 4 & $<1$ & 39.0 & 46.8 & 0.02 & nd & nd \\
\hline 44 & Le Prata $1^{\mathrm{g}}$ & sv & 95 & 8.44 & $<0.02$ & $<0.02$ & $<0.2$ & $<0.1$ & 622 & 61 & 1 & 23 & 0.6 & 196.2 & $<0.01$ & nd & nd \\
\hline 77 & Sasso Pisano ${ }^{\mathrm{g}}$ & $\mathrm{bp}$ & 98 & 5.80 & 0.05 & 2.5 & 94 & 18 & 47 & 499 & 5 & 248 & 116.0 & 90.0 & 0.04 & nd & nd \\
\hline 94 & Vagliagli 1 & $\mathrm{gp}$ & 17 & 5.66 & 85 & 2.3 & 175 & 19 & 265 & 409 & 41 & 36 & 4.6 & $<0.2$ & 0.01 & nd & nd \\
\hline 99 & Montemiccioli & gp & 15 & 4.90 & 40 & 10.5 & 485 & 54 & 98 & 1610 & 27 & 65 & 4.0 & 0.7 & 0.04 & nd & nd \\
\hline 100 & Borboi & $\mathrm{gp}$ & 13 & 5.88 & 35 & 3.1 & 723 & 57 & 915 & 1405 & 237 & 11 & $<0.03$ & 1.4 & 0.01 & nd & nd \\
\hline 102 & Montespertoli $^{\mathrm{h}}$ & $\mathrm{gp}$ & 22 & 6.20 & 62 & 2.7 & 360 & 146 & 1708 & 39 & 92 & 21 & nd & nd & nd & nd & nd \\
\hline 101 & Gambassi $^{\text {h }}$ & cs & 20 & 5.20 & 39 & 3.5 & 520 & 120 & nd & 1824 & 46 & 49 & 0.9 & nd & 0.05 & nd & nd \\
\hline 110 & Piersanti & cs & 16 & 6.09 & 312 & 7.0 & 619 & 134 & 2745 & 34 & 356 & 36 & 6.3 & 0.4 & 0.24 & nd & nd \\
\hline 128 & Cinciano & cs & 18 & 6.16 & 90 & 2.3 & 367 & 42 & 1299 & 96 & 56 & 22 & 36.6 & 0.6 & 0.03 & nd & nd \\
\hline 139 & Torre & $\mathrm{mc}$ & 29 & 8.70 & 3542 & 16.0 & 82 & 84 & 1238 & 92 & 5390 & nd & nd & nd & 0.80 & 1.3 & -15.8 \\
\hline 140 & Rivalta & $\mathrm{mc}$ & 31 & 8.55 & 5490 & 16.0 & 100 & 226 & 1202 & 88 & 8545 & nd & nd & nd & 0.80 & 5.7 & 10.1 \\
\hline 141 & Regnano & $\mathrm{mc}$ & 28 & 8.76 & 5731 & 20.0 & 40 & 57 & 1769 & 244 & 8190 & nd & nd & nd & 0.90 & 3.6 & -2.2 \\
\hline 142 & Nirano & $\mathrm{mc}$ & 27 & 8.34 & 4053 & 27.0 & 126 & 197 & 641 & 200 & 6335 & nd & nd & nd & 0.90 & 5.5 & 4.0 \\
\hline 143 & Ospitaletto & $\mathrm{mc}$ & 30 & 8.40 & 5106 & 20.0 & 160 & 125 & 793 & 164 & 8190 & nd & nd & nd & 0.70 & 5.9 & 9.1 \\
\hline
\end{tabular}

${ }^{a}$ nd: not determined.

${ }^{\mathrm{b}}$ ts = thermal spring; sv = steam vent; $\mathrm{bp}=$ boiling pool; $\mathrm{cs}=$ cold spring; $\mathrm{mc}=$ mud cone.

${ }^{c}$ Data after Duchi et al. (1992a).

${ }^{d}$ Data after Bencini et al. (1977).

${ }^{\mathrm{e}}$ Data after Arrigoni et al. (1982).

${ }^{\mathrm{f}}$ Data after Bencini and Duchi (1981).

g Data after Duchi et al. (1992b).

${ }^{\mathrm{h}}$ Data after Bencini et al. (1979).

mal springs south of the Arno River and steam condensates from the Larderello area are taken from the literature. Literature and new data on fluid samples from cold springs and waters associated with the thermal springs in the thrust belt and mud volcanoes in the foredeep areas are reported in Table 1.

As already stated, there is very well-developed deep circulation of thermal waters within the Mesozoic limestone formations in the periTyrrhenian sector of Italy. This may be the result of:

(1) anomalous heat-flow in and around the confined geothermal fields that have been little affected by cold meteoric inflows from outcrops;

(2) deep convective circulation in areas of thick- ening of the carbonate succession (tectonic wedges or thrust fronts; locally $>3000 \mathrm{~m}$; Buonasorte et al., 1991); and

(3) a contribution of both processes.

The Langelier-Ludwig diagram in Fig. 3 displays the general composition of the waters investigated. Thermal springs in central Italy generally have a $\mathrm{Ca}-\mathrm{SO}_{4}$ composition (typically sample 103 in Fig. 3) due to the dissolution of anhydrite layers below the Mesozoic limestones (Lotti, 1910; Trevisan, 1951). They may turn out to be either $\mathrm{Ca}-\mathrm{HCO}_{3}\left(\mathrm{SO}_{4}\right)$ close to the geothermal areas (samples 57 and 69) after $\mathrm{CO}_{2}$ solubilization (Duchi et al., 1987), or $\mathrm{Na}-\mathrm{HCO}_{3}$ after $\mathrm{Ca}-\mathrm{Na}$ ion exchange (sample 215) due to the contemporary presence of $\mathrm{CO}_{2}$ and clay material (Duchi 


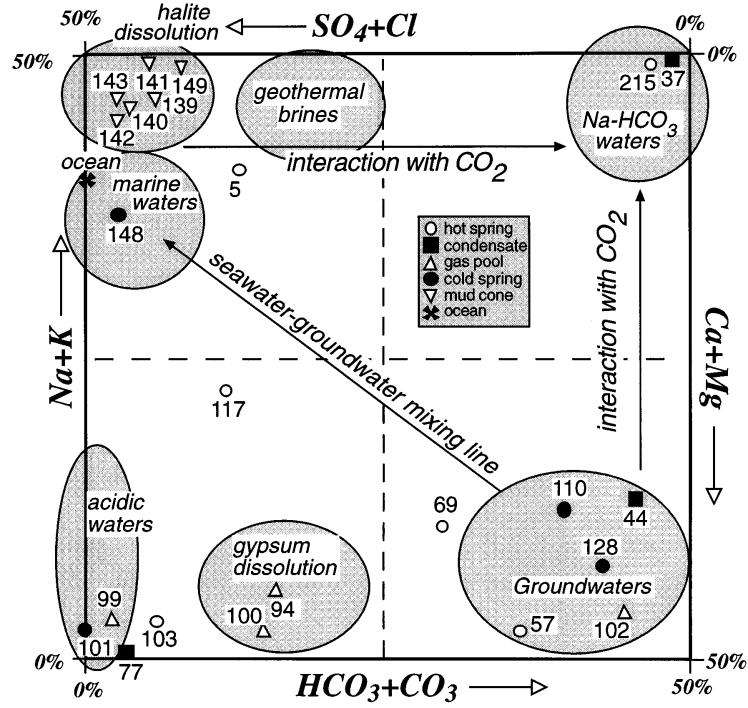

Fig. 3. Langelier-Ludwig diagram for the samples investigated.

et al., 1992a). Eventually, they may turn out to be $\mathrm{Na}-\mathrm{Cl}$ (sample 5) whether they mix with local connate waters or if they dissolve halite layers (Sestini, 1970a) embedded in the Mio-Pliocene post-orogenic sediments in the shallow parts of their flowing path (Francalanci, 1956). All these processes in the same carbonate reservoir may explain the relatively widespread distribution of the thermal water samples in the diagram, not constrained by a prevalent water-rock interaction process at depth.

Having a much shallower circuit, cold springs and waters associated with the gas vents should have the common $\mathrm{Ca}-\mathrm{HCO}_{3}$ composition of ground- and stream-waters in temperate regions (samples 102, 110 and 128) but, since they may circulate in the same formations of thermal springs above the Mesozoic limestones, they are also scattered all over the diagram. Moreover, solubilization of gypsum layers present inside the Miocene evaporites and local subaereal oxidation of $\mathrm{H}_{2} \mathrm{~S}$ of the associated gas phase may contribute to the shifting of some of them toward the $\mathrm{Ca}-\mathrm{SO}_{4}$ corner (samples 94, 99, 100 and 101).

Even the three fumarole steam condensate samples from Larderello [data from Duchi et al. (1992b)] have completely different compositions caused by different solubilization of components of the associated gas phase. Sample 37 is $\mathrm{NH}_{4}-\mathrm{HCO}_{3}$ in composition (Table 1) due to the solubilization of $\mathrm{NH}_{3}$ and $\mathrm{CO}_{2}$; sample 77 from a boiling pool has a $\mathrm{Ca}(\mathrm{H})-\mathrm{SO}_{4}$ acidic composition after $\mathrm{H}_{2} \mathrm{~S}$ oxidation to $\mathrm{SO}_{4}$ and subsequent solubilization; sample 44 is similar to sample 37 but can be regarded as distilled water (Table 1) and ideally can be located in the $\mathrm{Ca}(\mathrm{Na})-\mathrm{HCO}_{3}$ sector of the diagram.

Although scattered in a large area north of the Apennine watershed, more uniform $\mathrm{Na}-\mathrm{Cl}$ composition is shown by the waters associated with the $\mathrm{CH}_{4}$-rich mud volcanoes, suggesting a common source aquifer (brackish connate type solutions). Sample 215 in Fig. 3, although associated with a $\mathrm{CH}_{4}$-rich gas phase, differs from the other mud cone waters since it is a thermal spring emerging along an important NE-SW tectonic line (Arrigoni et al., 1982). Its composition $\left(\mathrm{Na}-\mathrm{HCO}_{3}\right)$ is possibly due to the fact that water and gas phases have different pathways (sources), sharing only the emergence orifice.

\section{Isotopic composition of waters}

Original data for waters from mud volcanoes, together with the ocean (SMOW: Standard Mean Ocean Water) and the Mediterranean Sea, are reported in Table 1 . They have been plotted in the $\delta \mathrm{D}-\delta^{18} \mathrm{O}$ diagram of Fig. 4 , which also includes data from wells in the Po Valley aquifers [data from Martinelli et al. (1998)] and other thermal springs in the Apennines [data from Minissale (1991b)]; this shows that most spring waters and groundwaters lie between the Global (Craig, 1963a) and the Mediterranean (Gatt and Carmi, 1970) Meteoric Water Lines. Samples 5 and 117, from south of Siena, show a small but significant ${ }^{18} \mathrm{O}$-shift likely due to the presence of undiscovered geothermal fluids in the Siena basin (Minissale et al., 1997b) whilst the mud cone waters suffered surface evaporation, as corroborated by the $\delta \mathrm{D}$ $\mathrm{Cl}$ (Fig. 5) and $\delta^{18} \mathrm{O}-\mathrm{Cl}$ (not shown) diagrams. The evaporation process in open air in the mud volcanoes is even more likely if we consider that 


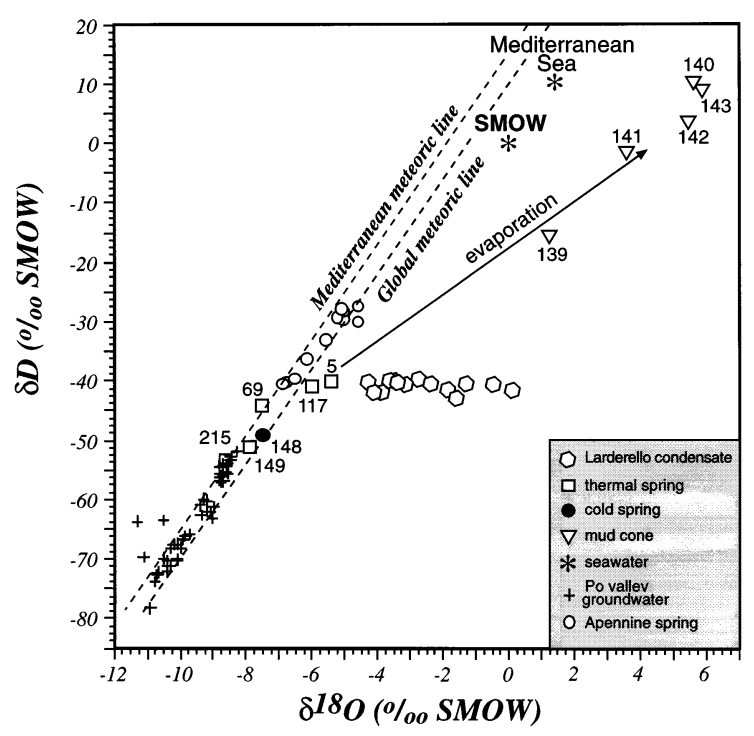

Fig. 4. $\delta^{18} \mathrm{O}-\delta \mathrm{D}$ diagram for most of the samples investigated. Data for Apennine springs are from Minissale (1991b). Data from wells in the Po Valley are from Martinelli et al. (1998). Data from Larderello well condensates are from Panichi et al. (1974).

the sampling campaign was carried out in July when the external temperature was $>35^{\circ} \mathrm{C}$.

If we consider that in the Langelier-Ludwig diagram (Fig. 3) the waters from the mud volca-

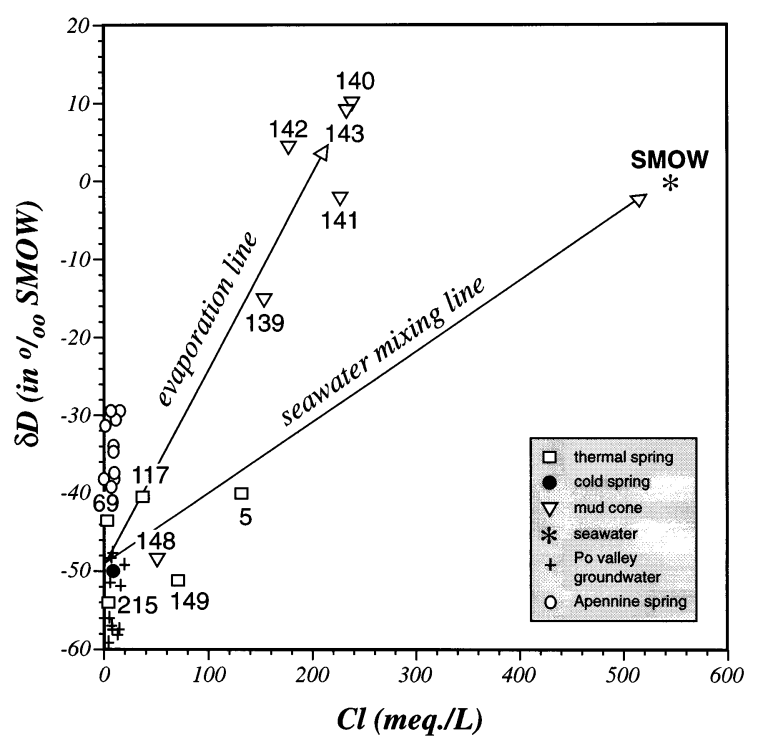

Fig. 5. $\delta \mathrm{D}-\mathrm{Cl}$ diagram for most of the waters investigated. noes locate in the $\mathrm{Na}-\mathrm{Cl}$ sector $(\mathrm{Na} / \mathrm{Cl}$ ratio near 1.0), whereas in Figs. 4 and 5 they are not aligned along the Global Meteoric Water Line and the seawater-groundwater mixing line (lower $\mathrm{Cl}$ and higher $\delta^{18} \mathrm{O}$ ratio with respect to seawater), we have to suppose that their chloride compositions do not derive from connate waters. It is likely due to the dissolution of halite layers embedded in the Miocene clay sediments.

As shown in Fig. 4, steam produced in the Larderello field has a clear meteoric signature, with highly shifted $\delta^{18} \mathrm{O}$ values but $\delta \mathrm{D}$ values similar to the $\delta \mathrm{D}$ of local rainfall (Craig, 1963b; Panichi et al., 1974).

\section{Chemistry of gases}

The chemical composition of gas samples discharging in the Northern Apennines is reported in Table 2 and the main components are plotted in the $\mathrm{CO}_{2}-\mathrm{CH}_{4}-\mathrm{N}_{2}$ ternary diagram of Fig. 6 . The $\mathrm{CO}_{2}$-rich samples pertain to the peri-Tyrrhenian belt, whereas the $\mathrm{CH}_{4}$-rich samples emerge from the thrust-belt and foredeep areas. Three samples (105, 146 and 148), located northwest of the study area (Apuan Alps, Fig. 2), have relatively high $\mathrm{N}_{2}$ contents. By plotting samples in the genetically more useful $\mathrm{N}_{2}-\mathrm{He}-\mathrm{Ar}$ diagram [Fig. 7, after Giggenbach et al. (1983)], modified by replacing the original 'andesitic' endmember with a more realistic, in non-active volcanic areas, 'metamorphic' endmember (Minissale et al., 1997a), relationships between gas compositions and potential sources are more evident. All the $\mathrm{CH}_{4}$-rich samples are relatively enriched in total $\mathrm{He}$, suggesting large production of crustal radiogenic ${ }^{4} \mathrm{He}$ and longtime residence of gases underground. On the contrary, gases associated with the thermal springs and the Larderello fumaroles have lower relative He contents, suggesting both a stronger contribution by air in their source and a lower residence time underground. This agrees well with the genetic interpretation of thermal waters whose isotopic signature suggests that they originate in the Mesozoic outcropping areas driving underground air-rich (low He content) rainfall in karstic circuits (Minissale et al., 1997a). 


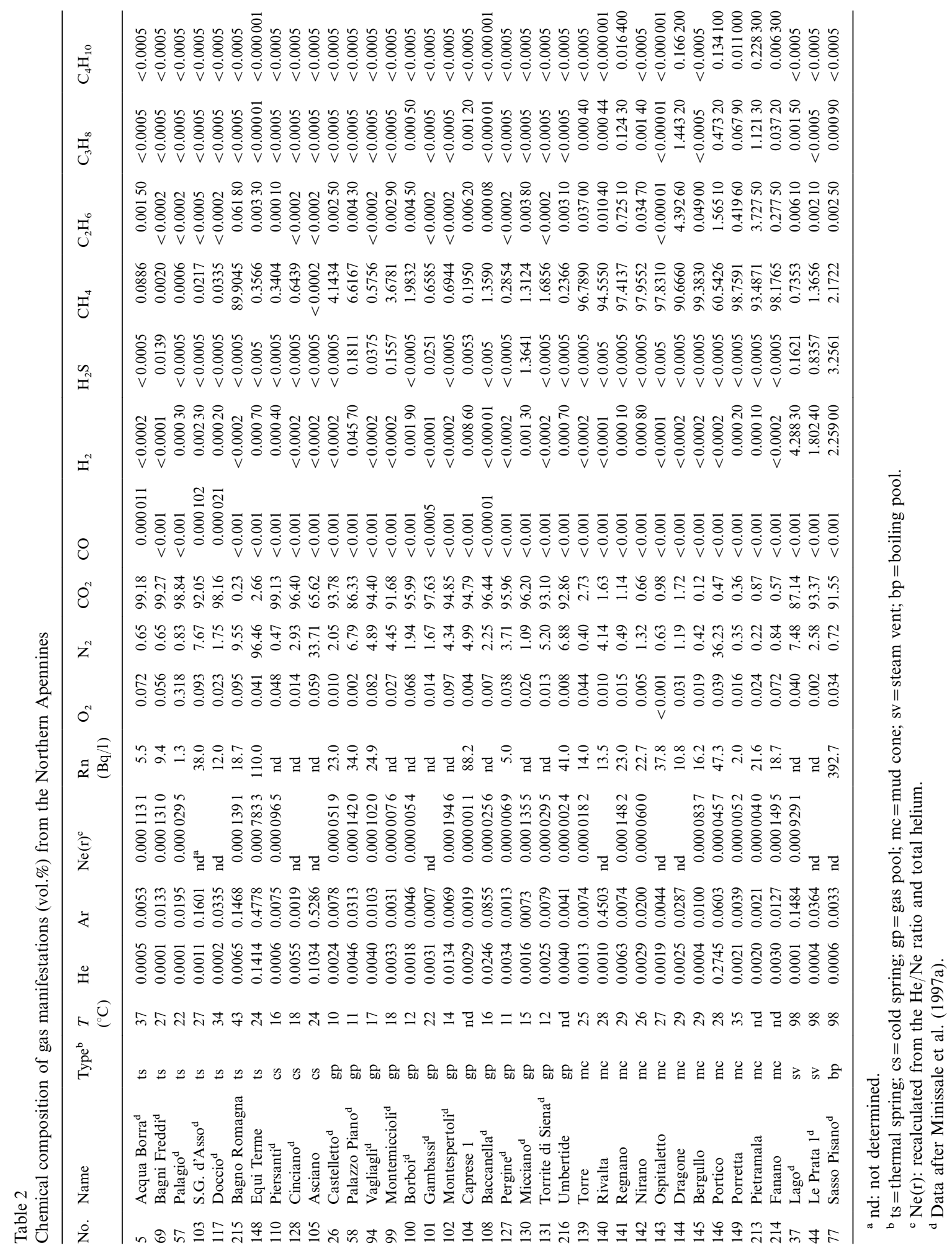




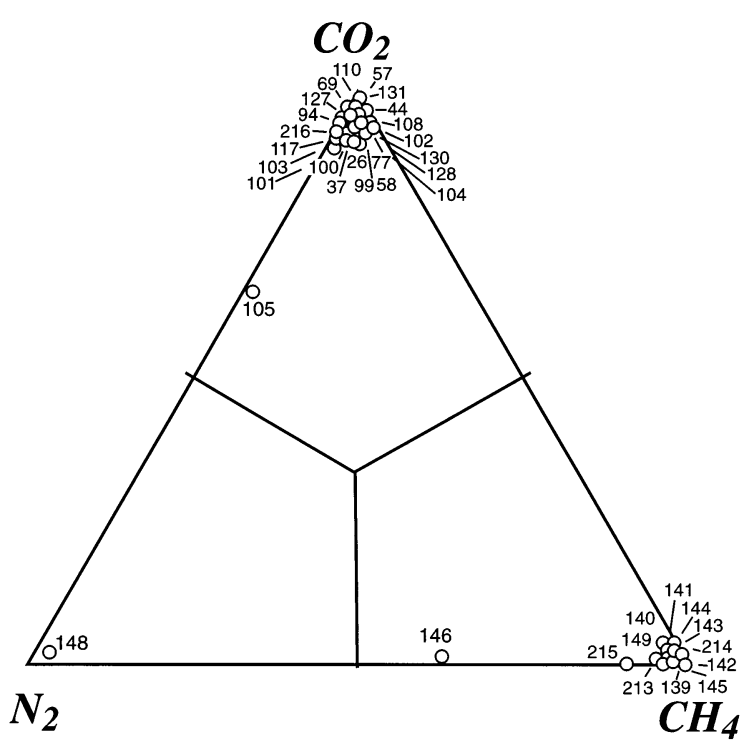

Fig. 6. $\mathrm{CH}_{4}-\mathrm{CO}_{2}-\mathrm{N}_{2}$ ternary diagram for the gas samples investigated.

Most cold $\mathrm{CO}_{2}$ emissions, with respect to the $\mathrm{CH}_{4}$-rich gases, although showing a low $\mathrm{He}$ content similar to the gases associated with the thermal springs, have high $\mathrm{N}_{2} /$ Ar ratios (2002000, Table 3), much higher than that in the air

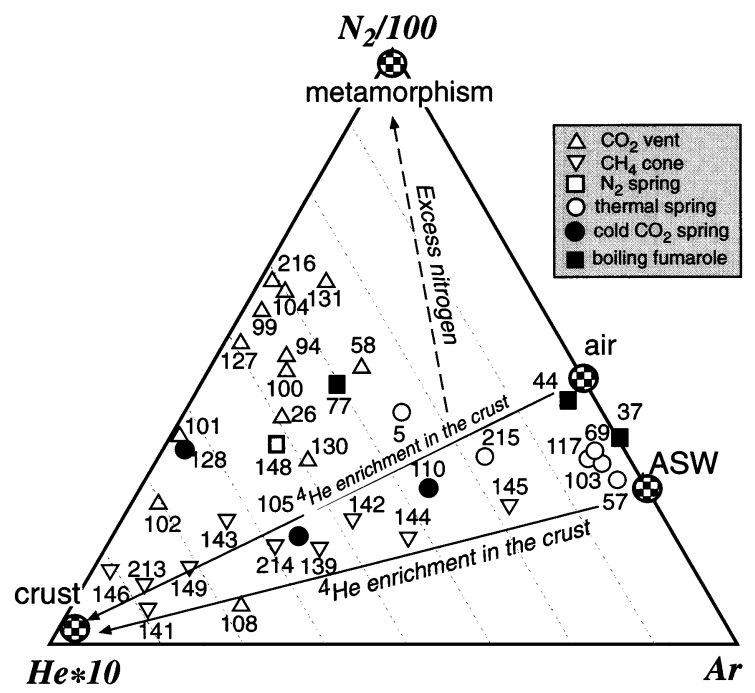

Fig. 7. $\mathrm{N}_{2}-\mathrm{Ar}-\mathrm{He}$ ternary diagram for the gas samples investigated. The figure shows the general increase in the total helium concentration in the crust, particularly evident for the $\mathrm{CH}_{4}$-rich samples. and air-saturated water ( 83 and 38 respectively, Fig. 8). This would suggest for $\mathrm{N}_{2}$ a partly different source with respect to the atmosphere. As the excess nitrogen shown by samples in Fig. 8 is correlated with positive $\delta^{15} \mathrm{~N}$ values (Table 1), $\mathrm{N}_{2}$-producing metamorphic processes inside the Paleozoic basement from Central Italy have been invoked (Minissale et al., 1997a) for these cold emissions. In places where gas sources are little affected by air-saturated water (ASW) driven at depth through the outcrops of the carbonates, they do not retain the air $\mathrm{N}_{2} / \mathrm{Ar}$ ratio.

\section{Isotopic composition of gases}

Isotope gas compositions for samples south of the Arno River are from Minissale et al. (1997a). Literature and new data are reported in Table 3.

As $\delta^{13} \mathrm{C}$ values in $\mathrm{CO}_{2}$ have been measured only on those samples where $\mathrm{CO}_{2}$ is $>1 \%$ (by volume), the data available are mostly concentrated in the peri-Tyrrhenian part. They vary from $-0.26 \%$ in the Larderello area to $-10.3 \%$ (PDB) north of Larderello, with a large number of samples in the range -4.0 to $-7.0 \%$. The $\delta^{13} \mathrm{C}$ values in the Larderello geothermal area reflect production of $\mathrm{CO}_{2}$ from hydrolysis and metamorphic reaction of limestones $\left(-2<\delta^{13} \mathrm{C}<2\right)$ in the hydrothermal reservoir. In the remaining areas they have been interpreted as either primary $\mathrm{CO}_{2}$ rising from the mantle (Marini and Chiodini, 1994) or mixing of isotopically heavy $\mathrm{CO}_{2}$ formed in the geothermal reservoir and isotopically light organic $\mathrm{CO}_{2}$ produced inside the Neogene basins (Minissale et al., 1997a).

The $\delta^{13} \mathrm{C}$ values in $\mathrm{CH}_{4}$ (measured in samples where $\mathrm{CH}_{4}>1 \%$ ) varies from -22.6 to about $-30.0 \%$ (PDB) south of the Arno river and from $<-30.0$ to $-69.7 \%$ o in the $\mathrm{CH}_{4}$-rich samples in the thrust belt and the Po Valley. The distribution pattern of more negative values roughly follows the boundary of the outcrops of the Apennine formations (Fig. 9). Values south of the Arno river are clearly in the range of thermogenic methane $\left(\delta^{13} \mathrm{C}<-30.0 \%\right)$, whereas north of the Apennine watershed, mixing of thermogenic and biogenic methane is likely to occur (Schoell, 1988). 
Table 3

Isotopic and chemical ratios of gas samples from the Northern Apennines

\begin{tabular}{|c|c|c|c|c|c|c|c|c|c|c|c|c|c|c|}
\hline No. & Name & Type & Latitude & Longitude & Elevation & $\begin{array}{l}T_{\mathrm{e}} \\
\left({ }^{\circ} \mathrm{C}\right)\end{array}$ & $\begin{array}{l}\delta^{13} \mathrm{C} \text { in } \\
\mathrm{CO}_{2}\end{array}$ & $\begin{array}{l}\delta^{13} \mathrm{C} \text { in } \\
\mathrm{CH}_{4}\end{array}$ & $\begin{array}{l}\delta^{15} \mathrm{~N} \text { in } \\
\mathrm{N}_{2}\end{array}$ & $\begin{array}{l}{ }^{3} \mathrm{He} / \\
{ }^{4} \mathrm{He}\end{array}$ & $\begin{array}{l}{ }^{3} \mathrm{He} / \\
{ }^{4} \mathrm{He}(\mathrm{c})\end{array}$ & $\begin{array}{l}{ }^{40} \mathrm{Ar} / \\
{ }^{36} \mathrm{Ar}\end{array}$ & $\mathrm{He} / \mathrm{Ne}$ & $\mathrm{N}_{2} / \mathrm{Ar}$ \\
\hline 5 & Acqua Borra & ts & $431828 \mathrm{~N}$ & $112541 \mathrm{E}$ & 200 & 37 & -5.95 & nd & nd & 0.29 & 0.17 & 295 & 2.0 & 123 \\
\hline 69 & Bagni Freddi & ts & $431758 \mathrm{~N}$ & $113610 \mathrm{E}$ & 290 & 27 & -7.54 & nd & nd & 0.43 & 0.13 & nd & 0.8 & 49 \\
\hline 57 & Palagio & ts & $432951 \mathrm{~N}$ & $105218 \mathrm{E}$ & 248 & 22 & -10.30 & nd & -0.51 & 2.33 & 2.79 & 295 & 1.1 & 42 \\
\hline 103 & S.G. d'Asso & ts & $430755 \mathrm{~N}$ & $113716 \mathrm{E}$ & 309 & 27 & -6.66 & nd & nd & nd & nd & nd & nd & 48 \\
\hline 117 & Doccio & ts & $430926 \mathrm{~N}$ & $111710 \mathrm{E}$ & 170 & 34 & -6.26 & nd & nd & nd & nd & nd & nd & 52 \\
\hline 215 & Bagno Romagna & ts & $434906 \mathrm{~N}$ & $115738 \mathrm{E}$ & 495 & 43 & nd & -56.2 & nd & 0.03 & 0.02 & nd & 48.6 & 65 \\
\hline 148 & Equi Terme & ts & $441008 \mathrm{~N}$ & $100940 \mathrm{E}$ & nd & 24 & nd & nd & nd & 0.05 & 0.04 & nd & 54.4 & 202 \\
\hline 110 & Piersanti & cs & $433406 \mathrm{~N}$ & $102512 \mathrm{E}$ & 30 & 16 & -6.71 & nd & nd & 0.16 & 0.14 & 295 & 13.3 & 62 \\
\hline 128 & Cinciano & cs & $433006 \mathrm{~N}$ & $111712 \mathrm{E}$ & 195 & 18 & -5.90 & nd & 0.60 & nd & nd & nd & nd & 1525 \\
\hline 105 & Asciano & cs & $434332 \mathrm{~N}$ & $102918 \mathrm{E}$ & 2 & 24 & -10.31 & nd & nd & 0.09 & 0.09 & 297 & nd & 64 \\
\hline 26 & Castelletto & gp & $431058 \mathrm{~N}$ & $110637 \mathrm{E}$ & 330 & 10 & -4.31 & -23.6 & 5.44 & 1.31 & 1.31 & 295 & 72.9 & 264 \\
\hline 58 & Palazzo Piano & gp & $431610 \mathrm{~N}$ & $110856 \mathrm{E}$ & 330 & 11 & -4.66 & -22.6 & 5.51 & 1.44 & 1.44 & 295 & 50.1 & 217 \\
\hline 94 & Vagliagli & gp & $432533 \mathrm{~N}$ & $112128 \mathrm{E}$ & 370 & 17 & -5.18 & nd & 1.27 & 0.13 & 0.08 & 330 & 5.5 & 473 \\
\hline 99 & Montemiccioli & gp & $432318 \mathrm{~N}$ & $110037 \mathrm{E}$ & 280 & 18 & -7.26 & -27.8 & 6.72 & 1.29 & 1.29 & 323 & 136.0 & 1417 \\
\hline 100 & Borboi & gp & $432634 \mathrm{~N}$ & $104303 \mathrm{E}$ & 215 & 12 & -9.31 & -29.6 & 5.53 & 0.07 & 0.07 & 370 & 232.0 & 422 \\
\hline 101 & Gambassi & gp & $433130 \mathrm{~N}$ & $105759 \mathrm{E}$ & 140 & 22 & -4.12 & nd & 5.38 & nd & nd & nd & nd & 2380 \\
\hline 102 & Montespertoli & gp & $433953 \mathrm{~N}$ & $110439 \mathrm{E}$ & 305 & 14 & -6.58 & nd & 1.80 & 0.03 & 0.02 & 295 & 64.1 & 629 \\
\hline 104 & Caprese 1 & gp & nd & nd & nd & nd & -4.21 & -38.5 & 0.84 & 0.03 & 0.03 & 378 & 2812.0 & 2626 \\
\hline 108 & Baccanella & gp & $433553 \mathrm{~N}$ & $104247 \mathrm{E}$ & 40 & 16 & -7.00 & nd & nd & 0.05 & 0.04 & nd & 39.0 & 26 \\
\hline 127 & Pergine & gp & $432852 \mathrm{~N}$ & $114120 \mathrm{E}$ & 246 & 11 & -6.93 & nd & -1.29 & 0.04 & 0.04 & 328 & 333.0 & 2853 \\
\hline 130 & Micciano & gp & $431628 \mathrm{~N}$ & $115216 \mathrm{E}$ & 340 & 15 & -6.06 & -26.5 & 4.90 & 1.23 & 1.23 & 295 & 15.2 & 149 \\
\hline 131 & Torrite di Siena & gp & $431058 \mathrm{~N}$ & $114301 \mathrm{E}$ & 370 & 12 & -3.87 & -30.8 & 6.13 & 0.11 & 0.11 & 295 & 64.7 & 660 \\
\hline 216 & Umbertide & gp & nd & nd & nd & nd & -3.57 & -26.7 & 2.61 & 0.02 & 0.02 & nd & 2485.0 & 1677 \\
\hline 139 & Torre & $\mathrm{mc}$ & $443712 \mathrm{~N}$ & $102017 \mathrm{E}$ & nd & 25 & nd & -39.1 & nd & 1.10 & 1.10 & 370 & 80.1 & 54 \\
\hline 140 & Rivalta & $\mathrm{mc}$ & $443744 \mathrm{~N}$ & $101934 \mathrm{E}$ & nd & 28 & nd & nd & nd & nd & nd & nd & nd & 9 \\
\hline 141 & Regnano & $\mathrm{mc}$ & $443325 \mathrm{~N}$ & $103434 \mathrm{E}$ & nd & 29 & nd & -44.9 & nd & 0.23 & 0.21 & 295 & 13.7 & 67 \\
\hline 142 & Nirano & $\mathrm{mc}$ & $443047 \mathrm{~N}$ & $104923 \mathrm{E}$ & nd & 26 & nd & -46.0 & nd & 0.04 & 0.03 & 326 & 35.5 & 66 \\
\hline 143 & Ospitaletto & $\mathrm{mc}$ & $442610 \mathrm{~N}$ & $105252 \mathrm{E}$ & nd & 27 & nd & nd & nd & nd & nd & nd & nd & 143 \\
\hline 144 & Dragone & $\mathrm{mc}$ & nd & nd & nd & 29 & nd & -43.8 & nd & nd & nd & nd & nd & 41 \\
\hline 145 & Bergullo & $\mathrm{mc}$ & $441829 \mathrm{~N}$ & $114413 \mathrm{E}$ & nd & 29 & nd & -69.7 & nd & 0.45 & 0.42 & 328 & 4.9 & 42 \\
\hline 146 & Portico & $\mathrm{mc}$ & nd & nd & nd & 28 & nd & -38.1 & -0.69 & 0.30 & 0.30 & nd & 2623.0 & 600 \\
\hline 149 & Porretta & $\mathrm{mc}$ & $440904 \mathrm{~N}$ & $115801 \mathrm{E}$ & nd & 35 & nd & -30.5 & nd & 0.04 & 0.04 & nd & 375.7 & 90 \\
\hline 213 & Pietramala & $\mathrm{mc}$ & nd & nd & nd & nd & nd & -36.6 & nd & 0.02 & 0.02 & nd & 800.0 & 106 \\
\hline 214 & Fanano & $\mathrm{mc}$ & nd & nd & nd & nd & nd & -30.5 & nd & 0.09 & 0.07 & nd & 20.9 & 66 \\
\hline 37 & Lago & $\mathrm{fu}$ & $430832 \mathrm{~N}$ & $104855 \mathrm{E}$ & 200 & 98 & -0.26 & nd & nd & 1.87 & 2.83 & nd & 0.6 & 50 \\
\hline 44 & Le Prata 1 & $\mathrm{fu}$ & $431111 \mathrm{~N}$ & $105027 \mathrm{E}$ & 280 & 98 & -3.40 & nd & nd & $1.73^{\mathrm{b}}$ & $2.53^{\mathrm{b}}$ & nd & 0.6 & 71 \\
\hline 77 & Sasso Pisano & $\mathrm{fu}$ & $431018 \mathrm{~N}$ & $105128 \mathrm{E}$ & 475 & 98 & -3.83 & -23.7 & 6.65 & $2.32^{\mathrm{b}}$ & $2.32^{\mathrm{b}}$ & nd & nd & 219 \\
\hline 150 & Riccione $^{\mathrm{a}}$ & $\mathrm{s}$ & nd & nd & nd & nd & - & - & - & $0.07^{\mathrm{c}}$ & $0.004^{\mathrm{c}}$ & - & 43 & - \\
\hline 151 & Fratta $^{\mathrm{a}}$ & s & nd & nd & nd & nd & - & - & - & $0.05^{\mathrm{c}}$ & 0.03 & - & 11.3 & - \\
\hline 74 & B.gni Galleraie ${ }^{a}$ & ts & $431123 \mathrm{~N}$ & $110122 \mathrm{E}$ & 340 & 27 & - & - & - & $1.31^{\mathrm{b}}$ & $1.34^{\mathrm{b}}$ & - & 35 & - \\
\hline 152 & Ciciano $^{\mathrm{a}}$ & ts & nd & nd & nd & 21 & - & - & - & $1.63^{\mathrm{b}}$ & $2.12^{\mathrm{b}}$ & - & 0.7 & - \\
\hline 153 & Bagnolo $^{\mathrm{a}}$ & ts & $430910 \mathrm{~N}$ & $105020 \mathrm{E}$ & 350 & 37 & - & - & - & $1.80^{\mathrm{b}}$ & $2.28^{\mathrm{b}}$ & - & 0.8 & - \\
\hline
\end{tabular}

$T_{\mathrm{e}}$ : emergence temperature; ${ }^{3} \mathrm{He} /{ }^{4} \mathrm{He}$ as $R / R_{\mathrm{a}} ;{ }^{3} \mathrm{He} /{ }^{4} \mathrm{He}(\mathrm{c})$ : corrected for air contamination on the basis of $\mathrm{He} / \mathrm{Ne}$ ratio according to Craig et al. (1978).

${ }^{\text {a }}$ Gas stripped from water.

${ }^{\mathrm{b}}$ Data from Hooker et al. (1985).

${ }^{\mathrm{c}}$ Data from Marty et al. (1992).

In samples where the $\mathrm{N}_{2} / \mathrm{Ar}$ ratio is greater than the air ratio (83) $\delta^{15} \mathrm{~N}$ measurements in $\mathrm{N}_{2}$ have been performed. As already pointed out, such high $\mathrm{N}_{2} / \mathrm{Ar}$ ratios (excess nitrogen) are found in the $\mathrm{CO}_{2}$-rich gas samples (south of the Arno river), generally not associated with the thermal spring gas. $\delta^{15} \mathrm{~N}$ values vary from -1.3 to $+6.72 \%$ o (NBS), with most values generally greater than 


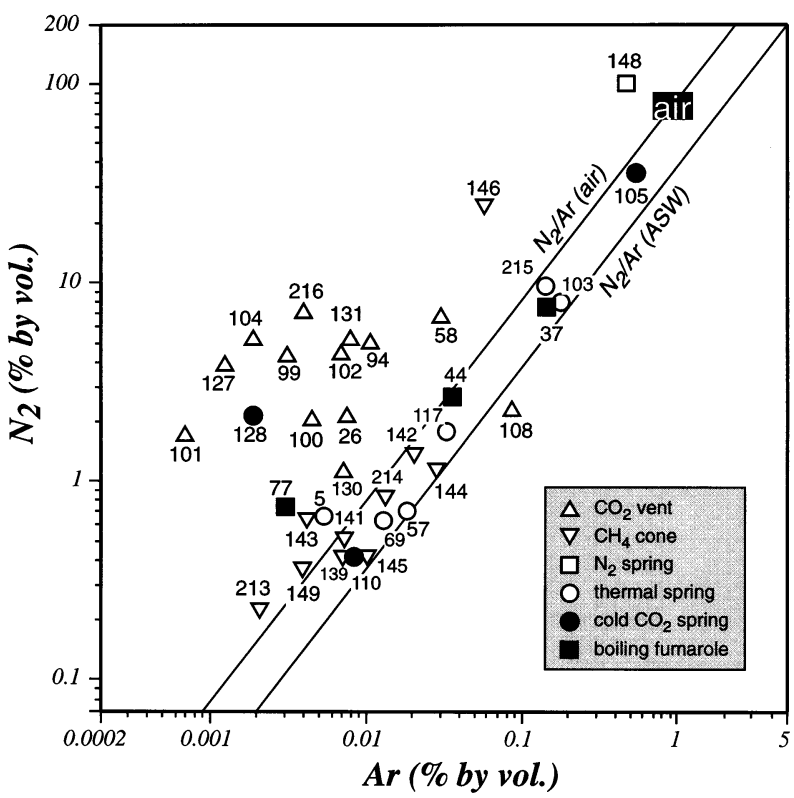

Fig. 8. $\mathrm{N}_{2}-\mathrm{Ar}$ diagram for the gas samples investigated. Most $\mathrm{CO}_{2}$-rich emissions not associated with liquid phases (both hot and cold) show some 'excess nitrogen' with respect to $\mathrm{N}_{2}$ stricly deriving from air or air-saturated water (ASW; see text).

zero, and have been interpreted as due to the production of $\mathrm{N}_{2}$ from $\mathrm{NH}_{4}$-rich $\mathrm{K}$-feldspars and micas inside the Paleozoic metamorphic basement (Minissale et al., 1997a).

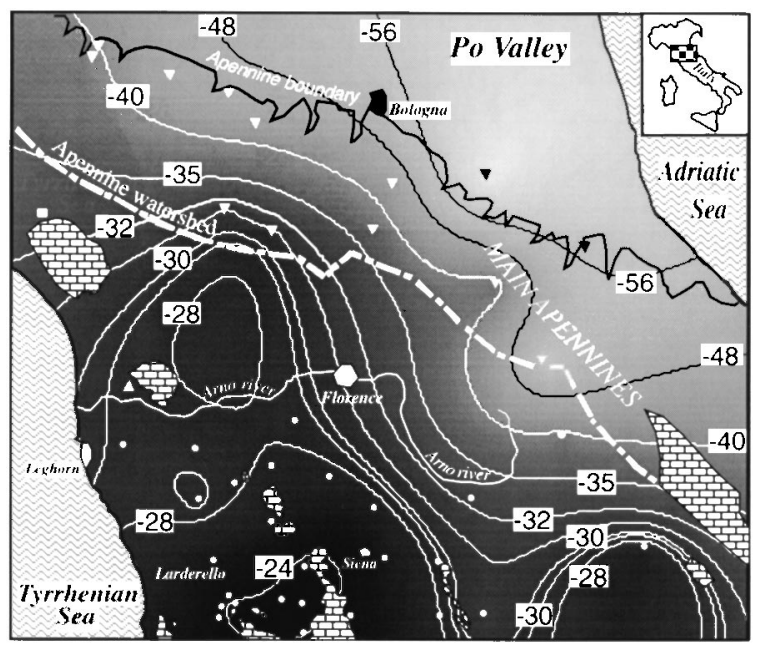

Fig. 9. Map showing curves of $\delta^{13} \mathrm{C}$ isoconcentration in $\mathrm{CH}_{4}$ (see text). Same symbology as in Fig. 2 apart from color (isocontour lines are white when in dark background).
${ }^{3} \mathrm{He} /{ }^{4} \mathrm{He}$ ratios as $R / R_{\mathrm{a}}$ (where $R={ }^{3} \mathrm{He} /{ }^{4} \mathrm{He}$ in the sample and $R_{\mathrm{a}}$ is ${ }^{3} \mathrm{He} /{ }^{4} \mathrm{He}$ in the air is $1.34 \times 10^{-6}$; Mamyrin and Tolstikhin, 1984), corrected for air contamination on the basis of the $\mathrm{He} / \mathrm{Ne}$ ratio (Craig et al., 1978) vary, in both the free gas vents and gases stripped from thermal waters, from typical crustal values (0.02) in a large part of the study area, to values up to 2.32 at Larderello and nearby areas (Fig. 10). By considering a mantle $R / R_{\mathrm{a}}$ value of 8.0 (Craig et al., 1978), in this area Hooker et al. (1985) have suggested the presence of $30 \%$ mantle component in the gas phase, which may achieve up to $40 \%$ when the European lithospheric mantle $\left(R / R_{\mathrm{a}}=6.1-6.7\right.$; Dunai and Baur, 1995) is considered.

\section{The Larderello area}

The geothermal gradient at Larderello is really very high, reaching locally $250^{\circ} \mathrm{C} / \mathrm{km}$, due to the presence of convective circulation of steam shallow in the crust. The origin and evolution in time of fluids in such a high thermal area have extensively been stressed in the geothermal literature (Goguel, 1953; Sestini, 1970b; D'Amore and Truesdell, 1979; Minissale, 1991a; Manzella et al., 1998 and refer-

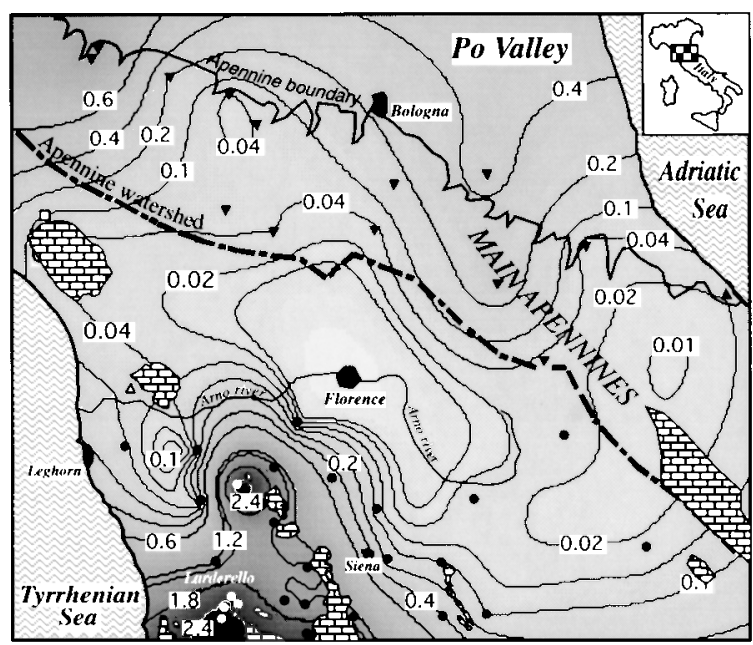

Fig. 10. Map showing isoconcentration curves of ${ }^{3} \mathrm{He} /{ }^{4} \mathrm{He}$ ratio (as $R / R_{\mathrm{a}}$ ) in the gas phase (see text). Same symbology as in Fig. 2. 
ences cited therein). Based on the relative concentration of minor components in the gas phase, several gas geothermometers have been gauged in this area (D'Amore and Panichi, 1980; Bertrami et al., 1985; Giggenbach 1991). Among the many peculiarities that characterize the field, it is worth remembering that it produces, at present, $300 \mathrm{t} / \mathrm{h}$ of highly depressurized dry steam with 5 to $10 \%$ of $\mathrm{CO}_{2}$-rich gas phase of total fluid production. The total amount of minor components (such as $\mathrm{H}_{2}, \mathrm{H}_{2} \mathrm{~S}, \mathrm{CH}_{4}, \mathrm{~N}_{2}$, Ar) quite often exceeds $10 \%$ of total gas whether the gas discharges from the producing wells or from the natural ground steam emissions (Duchi et al., 1992b).

By moving away from Larderello there is an abrupt decrease in the less soluble components (particularly $\mathrm{H}_{2}$ ) in the gas vents not associated with steam, even if they are located in the area where deeper marginal producing geothermal wells are still present (i.e. samples 130 and 26 in Fig. 2). This suggests that $\mathrm{H}_{2}, \mathrm{H}_{2} \mathrm{~S}$ and $\mathrm{CH}_{4}$ are mostly produced inside the geothermal reservoir through gas-gas reactions whose kinetics are favored by the presence of the vapor phase (i.e. FischerTropsch-type reactions; D'Amore and Nuti, 1977; Chiodini and Marini, 1998). They can reach the surface as natural components only where the cap rock over the carbonate reservoir is reduced in thickness, as in the center of the field itself.

As already stated, the Larderello fluid is also characterized by a clear mantle signature in the gas phase as seen from the relatively high ${ }^{3} \mathrm{He} /$ ${ }^{4} \mathrm{He}$ ratio. With respect to $\mathrm{H}_{2}$ and the other minor gas components, that do not overcome the steam discharging area, the more conservative ${ }^{3} \mathrm{He} /{ }^{4} \mathrm{He}$ ratio has a much larger areal extension in the gas vents outside the field with respect to the field itself (Fig. 10). This suggests that not only the Larderello field but a large part of southern Tuscany is actually affected by an upwelling of the mantle. In fact, the Moho depth in a large sector of southern Tuscany is as low as $20-25 \mathrm{~km}$ (Calcagnile and Panza, 1979).

Another typical feature of the Larderello gas, with respect to the rest of the study area, is represented by the isotopic composition of carbon in the $\mathrm{CO}_{2}$ (Fig. 11). In a regional panorama with markedly $<-4.0$ values, likely caused by either

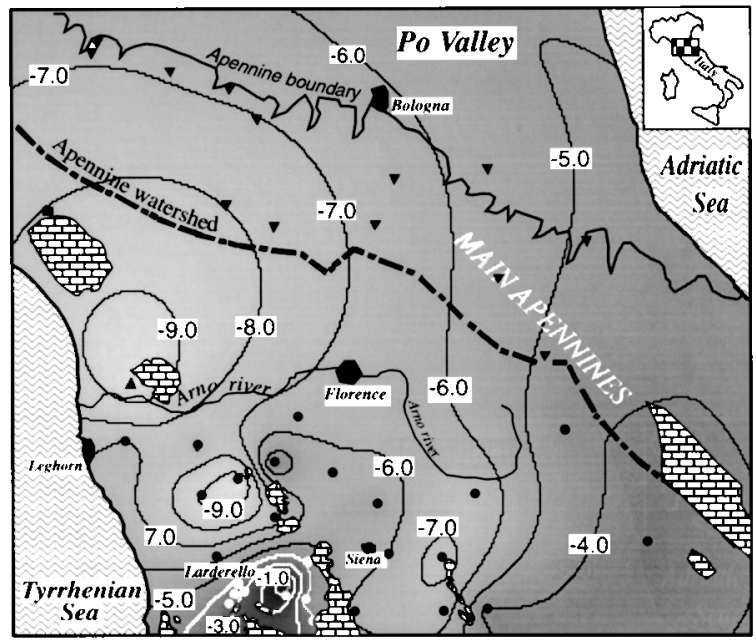

Fig. 11. Map showing isoconcentration curves of $\delta^{13} \mathrm{C}$ in $\mathrm{CO}_{2}$ (see text). Same symbology as in Fig. 2 apart from color (white when in dark background).

the presence of isotopically light organic-derived $\mathrm{CO}_{2}$ inside the Neogene basins (Minissale et al., 1997a) and the Po Valley (Mattavelli and Novelli, 1987) or mantle-derived $\mathrm{CO}_{2}, \delta^{13} \mathrm{C}$ values at Larderello have less negative values. They are well in the range of $\mathrm{CO}_{2}$ produced through the hydrothermal alteration of marine limestones. If we consider the presence of 30 to $40 \%$ mantle gas at Larderello as suggested by the ${ }^{3} \mathrm{He} /{ }^{4} \mathrm{He}$ ratio, we would have expected a more negative mantle-type value $(-3.0 /-8.0$; Rollison, 1993), or at least values similar to the rest of the study area. The reason for such relatively less negative values may have to be related to the presence of huge quantities of metamorphic $\mathrm{CO}_{2}$ produced inside the main carbonate reservoir and the underlying metamorphic basement, following water-rock reactions such as those proposed by Gianelli (1985) and Gianelli and Calore (1996).

\section{Origin of $\mathrm{N}_{2}, \mathrm{CO}_{2}$ and $\mathrm{CH}_{4}$ in the gas phase}

Isocontour maps of $\mathrm{N}_{2}, \mathrm{CH}_{4}$ and $\mathrm{CO}_{2}$ in the gas phase in the study area are shown in Fig. 12 (top, center and bottom respectively). The main distinguishing feature of the cross-comparison of such maps is the clear separation existing between 


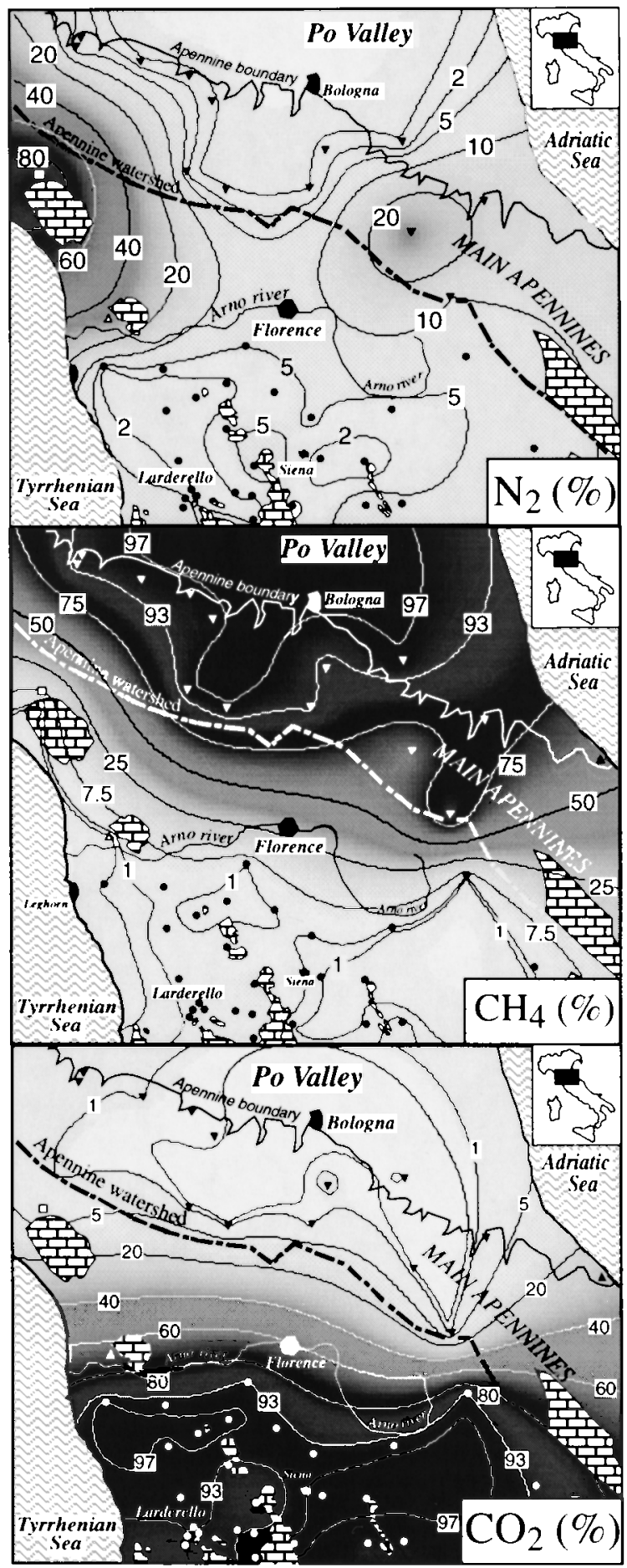

the $\mathrm{CH}_{4}$ domain in the foredeep areas compared with both the $\mathrm{CO}_{2}$ domain in the peri-Tyrrhenian internal sector and the $\mathrm{N}_{2}$-rich realm centered on the massive, thick marble range of the Apuan Alps. The Apennine watershed seems to mark a boundary limit of the emergence of natural $\mathrm{CO}_{2}$-rich gas vents, whose northernmost and easternmost discharges are clearly related to the more external post-orogenic basins (samples 110, 108, 102, 127, 104 and 216 in Fig. 2). Methane dominates both emergences along the thrust belt area (samples 149, 213, 214 and 215), as well as in the gas vents emerging at the boundary limit between the Apennine outcrops and the Neogene material in the Po Valley (samples 139, 140-143, 145 and 151). Moreover, several gas fields were discovered and exploited after the Second World War in both the Po Valley and the Adriatic Sea (Fig. 1).

By focusing the attention firstly on the origin of nitrogen (Fig. 8), it is very likely that the main source of this component is atmospheric in origin. In fact, all the $\mathrm{CH}_{4}$-rich samples in Fig. 8, the gas samples associated with the thermal springs, the Larderello fumaroles and some of the cold $\mathrm{CO}_{2}$-rich gas emissions associated with cold springs have a $\mathrm{N}_{2} / \mathrm{Ar}$ ratio similar to those in the air or ASW. This could be due to the fact that the carbonate formations host a powerful regional aquifer that gathers huge quantities of rainfall in their outcrop areas, generally coinciding with the main mountains in central-southern Italy, as well as water leaking from the overlying Oligocene turbiditic formations. This is also true even at Larderello, which, although having a clear submagmatic thermal origin (Goguel, 1953; Sestini, 1970b; D'Amore and Bolognesi, 1994), is mostly supplied by meteoric waters (Craig, 1963b; Calore et al., 1982),

If the production (and/or rise) of either $\mathrm{CH}_{4}$ or $\mathrm{CO}_{2}$ are prevailing over the exsolution of $\mathrm{N}_{2}$ from recharge ASW, as happens in most parts of the study area, $\mathrm{N}_{2}$ remains a minor diluted compo-

Fig. 12. Isodistribution maps of $\mathrm{N}_{2}, \mathrm{CH}_{4}$ and $\mathrm{CO}_{2}$ (in percentage of the total gas phase) in the gas phase (see text). Same symbology as in Fig. 2 apart from color (isocontour lines are white when in dark background). 
nent. On the contrary, when active sources of $\mathrm{CH}_{4}$ (both biogenic and thermogenic) and $\mathrm{CO}_{2}$ (both geothermal and metamorphic) are of secondary importance, as in the Apuan Alps (one of the rainiest areas in Italy), $\mathrm{N}_{2}$ becomes the main residual component. This kind of $\mathrm{N}_{2}$-rich emission (sample 148), emerging as gentle intermittent bubbles associated with cold or hot waters, is widespread all over the world (e.g. Jenden et al., 1988; Minissale et al., 1988, 1999a; Toutain and Baubron, 1998; Casiglia et al., 1999) and in several places of Italy (e.g. Minissale et al., 1997a, 1998). Generally speaking, in central-northern Italy they reflect either the presence of air along the shallower levels of the gas rising pathways (cold spring) or a deep circulation of meteoric-derived waters (thermal spring) in those sectors where geothermal $\mathrm{CO}_{2}$-rich fluids are confined.

As far as the origin of $\mathrm{CO}_{2}$ in the periTyrrhenian area is concerned, it is clear that, apart from a relatively small quantity derived from the hydrolysis of carbonates inside the Mesozoic limestones (Kissin and Pakhomov, 1967; Panichi and Tongiorgi, 1976), the largest part is both from mantle degassing (Minissale 1991b; Marini and Chiodini, 1994) and thermometamorphic reactions involving the formations of authigenic calcium silicate veins in the crystalline basement (Gianelli, 1985).

Since limestones may act, when buried, as a huge regional trap for fluids, both descending $\mathrm{N}_{2}$ and rising $\mathrm{CO}_{2}$ tend to be accumulated inside the Mesozoic carbonate unit because of its very high secondary permeability. Their relative proportions in the gas vents at the surface is a function of either the quantity of $\mathrm{CO}_{2}$ produced at depth in the geothermal fields or $\mathrm{N}_{2}$-rich meteoric waters flowing down from the carbonate outcrops. As with what happens for the gas phase, the composition of the associated thermal waters may also change from $\mathrm{Ca}-\mathrm{SO}_{4}$ (stronger meteoric component: samples 103 and 117 in Fig. 3) to $\mathrm{Ca}(\mathrm{Na})-\mathrm{HCO}_{3}$ (stronger geothermal $\mathrm{CO}_{2}$-rich component: samples 57 and 69 in Fig. 3) (Minissale and Duchi, 1988).

A quantitative assessment made on producing wells in the Po Valley, Adriatic coast and offshore gas fields (group 1) indicates that $80 \%$ of methane produced in the Apennine foredeep-basins is gener- ated through bacterial activity, whereas the remaining $20 \%$ is from thermal degradation of organic matter (Mattavelli and Novelli, 1987). On the contrary, in the peri-Tyrrhenian belt (group 2) most $\mathrm{CH}_{4}$ is thermogenically originated, whereas bacterial methane is produced inside the Neogene basins only to a very minor extent (Minissale et al., 1997a). The isodistribution map of $\delta^{13} \mathrm{C}$ in $\mathrm{CH}_{4}$ (Fig. 9) clearly shows that there is a progressive increase in isotopically light biogenic methane towards the Po Valley.

Although the $\delta^{13} \mathrm{C}$ values suggest a mixed character due to the presence of deep rising thermogenic methane $\left(\delta^{13} \mathrm{C}\right.$ in $\left.\mathrm{CH}_{4}>-40 \%\right)$, all the methane-rich samples from shallow seeps that discharge at the boundary limit of the Apennine outcrop formations (samples 139, 140, 142, 143 and 145) belong to group 1. The associated liquidphase composition, i.e. saline $\mathrm{Na}-\mathrm{Cl}$ composition and heavy hydrogen and ${ }^{18} \mathrm{O}$ signature, for which an origin from marine waters entrapped inside the thrusted Mio-Pliocene sediments that border the Northern Apennines is claimed, also stresses their quite shallow origin.

The remaining samples located in the main thrust belt area (samples 214, 149, 213 and 146) have a more thermogenic character $\left(-36.0<\delta^{13}\right.$ $\mathrm{C}<-38.0 \%$; Table 3 ). The increased maturity of methane in this southern area with respect to the group 1 of gases is due to the fact that producing reservoirs are prevalently associated with the underlying Oligo-Miocene sandstones (Borgia et al., 1988). These formations (upper part of the Tuscan Unit), which represented the foredeep sediments during the first Tortonian compressive phases (Costa et al., 1998), now translated towards east by the compressive wave, have, in places, been buried by the allochthonous Ligurian nappes. They likely underwent higher Tortonian thermal gradients compared with the Po Valley sediments. Although speculative, such local anomalous Miocene thermal gradients can be envisaged in some Miocene andesites crossed by a deep well (from $3858 \mathrm{~m}$ downwards) in the thrust belt area below the Mesozoic sequence (Anelli et al., 1994). Such andesites, completely missing at the surface in the Northern Apennines, have been thrusted by the Tuscan sequence during the main compressive Tortonian phase. 


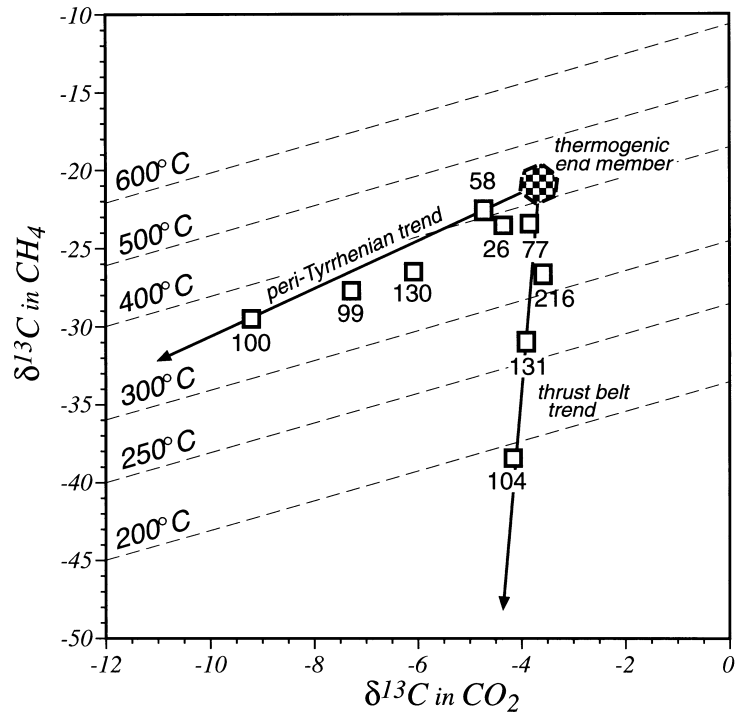

Fig. 13. $\delta^{13} \mathrm{C}$ in $\mathrm{CO}_{2}-\delta^{13} \mathrm{C}$ in $\mathrm{CH}_{4}$ binary diagram. Two different trends are evident for samples in the peri-Tyrrhenian sector and samples located in the thrust belt area.

\section{Relation between $\mathrm{CH}_{4}$ and $\mathrm{CO}_{2}$}

As discussed by Minissale et al. (1997a), in the peri-Tyrrhenian sector of Italy $\mathrm{CO}_{2}$ may be produced from: (1) the lithospheric mantle; (2) the crystalline basement; (3) the Mesozoic limestones; (4) the Neogene basins. Mantle should produce $\delta^{13} \mathrm{C}$ values in $\mathrm{CO}_{2}$ between -8.0 and $-3.0 \%$; those from the crystalline basement and the carbonate rocks should vary from -2.0 to $2.0 \%$, whereas the alteration of organic material in the Neogene basin would produce $\mathrm{CO}_{2}$ with much more negative $(<-20 \%$ ) values (i.e. samples 57 and 100 in Table 3 ). Based on such different genetic environments, $\mathrm{CO}_{2}$ vents with variable $\delta^{13} \mathrm{C}$ in this area are probably to be expected. On the other hand, with the heat-flow of the peri-Tyrrhenian sector being distinctively anomalous with respect to the main thrust belt and foredeep areas, one might expect a more uniform thermogenic $\delta^{13} \mathrm{C}$ distribution in $\mathrm{CH}_{4}$ with respect to the foredeep area. Such considerations seem to be confirmed by plotting $\delta^{13} \mathrm{C}$ values in $\mathrm{CH}_{4}$ versus $\delta^{13} \mathrm{C}$ in $\mathrm{CO}_{2}$ [Fig. 13, after Giggenbach (1982)]. Two distinct trends can be recognized. The first lies on the $350^{\circ} \mathrm{C}$ isotherm and refers to gases located in the
peri-Tyrrhenian and Larderello sectors (samples 100, 99, 130, 26, 58 and 77, Table 2), characterized by a narrow range of $\delta^{13} \mathrm{C}$ values in $\mathrm{CH}_{4}$ and highly variable $\delta^{13} \mathrm{C}$ in the $\mathrm{CO}_{2}$. The second (lower equilibration temperature) includes samples from the easternmost basins of the peri-Tyrrhenian area (samples 104, 131 and 216, Table 2), characterized by fairly constant $\delta^{13} \mathrm{C}$ values in $\mathrm{CO}_{2}$ and relatively variable $\delta^{13} \mathrm{C}$ in $\mathrm{CH}_{4}$. Both trends seem to point to a common pure thermogenic endmember that, in flowing to the surface, mixes with $\mathrm{CO}_{2}$ deriving from shallower sources in the peri-Tyrrhenian sector and shallower $\mathrm{CH}_{4}$ in the thrust-belt and foredeep basins.

\section{He isotopes and active compression in the Northern Apennines}

Both the shallow Moho depth in the periTyrrhenian sector and the somehow 'ambiguous' $\delta^{13} \mathrm{C}$ values in $\mathrm{CO}_{2}$ (Fig. 11) may suggest that this inner sector of the Apennines is the result of discharge of fluids from the mantle. A much more reliable isotopic ratio, able to detect unequivocally even small mantle degassing components in surface fluids inside the continental crust, is the ${ }^{3} \mathrm{He} /{ }^{4} \mathrm{He}$ ratio (O'Nions and Oxburgh, 1988). In particular, if for crustal production of ${ }^{4} \mathrm{He}$ by $\mathrm{U}$ and $\mathrm{Th}$ decay the $R / R_{\mathrm{a}}$ ratio is within the range 0.005 0.02 (Andrews, 1985), for $R / R_{\mathrm{a}}>0.2$ the presence of mantle ${ }^{3} \mathrm{He}$ is generally accepted (Marty et al., 1992). Apart from the area centered on the Larderello geothermal field, where intrusive magmatics have recently been crossed by deep wells (Villa et al., 1987), and a smaller area north of it, centered on sample 57, in coincidence with the presence of two small Pliocene volcanic outcrops of orendite rocks (Conticelli et al., 1992), the isocontour map of $R / R_{\mathrm{a}}$ (Fig. 10) suggests that the remaining larger part of the study area shows near-crustal values. This is in spite of the fact that several well-developed Neogene basins, e.g. Siena, Chiana, Tevere, Upper Arno basins, in the inner part of the Apennine thrust belt should favor the rising of deep fluids along their boundary fault systems. These basins have been considered as the result of tensive tectonics that characterized the 
inner part of the Appennines after the Tortonian compressive phase, consequent to the opening of the Tyrrhenian Sea as a back-arc basin (Boccaletti and Guazzone, 1974).

As a matter of fact, the presence of mantlederived ${ }^{3} \mathrm{He}$ fluid discharges has been reported in several extensional areas of Europe (Martel et al., 1989; Griesshaber et al., 1992) in relation to the escape to the surface of mantle fluids. Since the anomalous emission of ${ }^{3} \mathrm{He}$ in the study area is strictly related to the presence of magmatic rocks, at both depth and at the surface, even if as old as 2-3 Ma, we believe that basins in the periTyrrhenian belt of the Apennines north and east of Larderello do not have to be considered as back-arc-related basins. On the contrary, with the ${ }^{3} \mathrm{He} /{ }^{4} \mathrm{He}$ ratio of samples located in the Tevere (samples 104 and 216), upper Arno (sample 127), Era (samples 100 and 108), Elsa (sample 102) and Fine basins (sample 110) in the range 0.02-0.16, such basins have to be regarded as piggy-back (or thrust-top) basins. They are not deeply rooted in the crust and have developed and evolved in a compressive tectonic regime. Furthermore, most of these basins show intense compressive PlioQuaternary structural features (Boccaletti et al., 1992; Bonini et al., 1999).

As expected, the ${ }^{3} \mathrm{He} /{ }^{4} \mathrm{He}$ ratios from gases in the main thrust belt of the Apennines (in an area characterized by high seismicity, compression and thicker crust) show typical crustal values, with the exception of sample 139 which shows an anomalous $R / R_{\mathrm{a}}=1.1$ value. Since this sample is very little affected by air contamination during sampling $\left(R / R_{\mathrm{a}}=1\right.$ in the air), we must suppose that this northwesternmost sample might reflect a local situation where extension prevails over compression, thus allowing ${ }^{3} \mathrm{He}$ to rise.

\section{Relation between seismicity, tectonics and fluids}

The eastward migration of extensional-compressional post-Miocene phases of the Northern Apennines towards the rigid block represented by the Adriatic plate has caused the formation of several progressively younger thrust fronts. Some of these fronts are buried below the sediments in the Po Valley (Fig. 14). As already marked by the limit between the $\mathrm{CH}_{4}$ and $\mathrm{CO}_{2}$ domains, the Apennine watershed, coinciding with the first Tortonian thrust front, also marks a limit of seismicity. The distribution of earthquakes with $M>2.6$ in the period 1988-1995 (Fig. 14; Frepoli and Amato, 1997) shows that the number of earthquakes in the inner $\mathrm{CO}_{2}$-producing periTyrrhenian sector dramatically decreases compared with that in the $\mathrm{CH}_{4}$-producing thrust belt and foredeep areas. The seismic belt along and north of the Apennine watershed more or less coincides with the abrupt limit between the $\mathrm{CO}_{2}$ and the $\mathrm{CH}_{4}$ domains. This limit also marks the boundary limit of the Adriatic plate below the Apennines (Calcagnile and Panza, 1982). The Adriatic plate, whose subduction after the Tortonian caused the formation of the Apennine chain, is made up of continental lithosphere with thickness increasing from $70 \mathrm{~km}$ in southern Italy to more than $110 \mathrm{~km}$ in the Northern Apennines. It acts, at present, as a rigid block surrounded by $50-80 \mathrm{~km}$ seismically active belts (Frepoli and Amato, 1997). Seismic energy release at the western boundary of the Adriatic plate has recently been found to be correlated with the topographic top of the Apennine Range (De Rubeis et al. 1992; Selvaggi et al., 1997).

At the $\mathrm{CO}_{2}-\mathrm{CH}_{4}$ geochemical boundary along the Apennine watershed, a subcrustal seismic activity has recently been evidenced by Selvaggi and Amato (1992). Such deep seismic activity suggests that the Adriatic lithosphere is probably still subducting beneath the Northern Apennines. Thermometamorphic $\mathrm{CO}_{2}$ discharging in the internal tensive belt of the Northern Apennines could be interpreted as the geochemical signature of subductive processes involving limestones (Amato et al., 1993), with contemporary injection of mantle-derived magmas. Although several mantle magmatics were sporadically emitted in the Pliocene in Tuscany (Conticelli et al., 1992), at present still-degassing mantle-derived magmas may be hypothesized to be present at depth only in the Larderello geothermal area.

Metamorphic processes and circulation of twoor three-phase fluids, both descending and ascending, are likely to be the cause of the limited number 


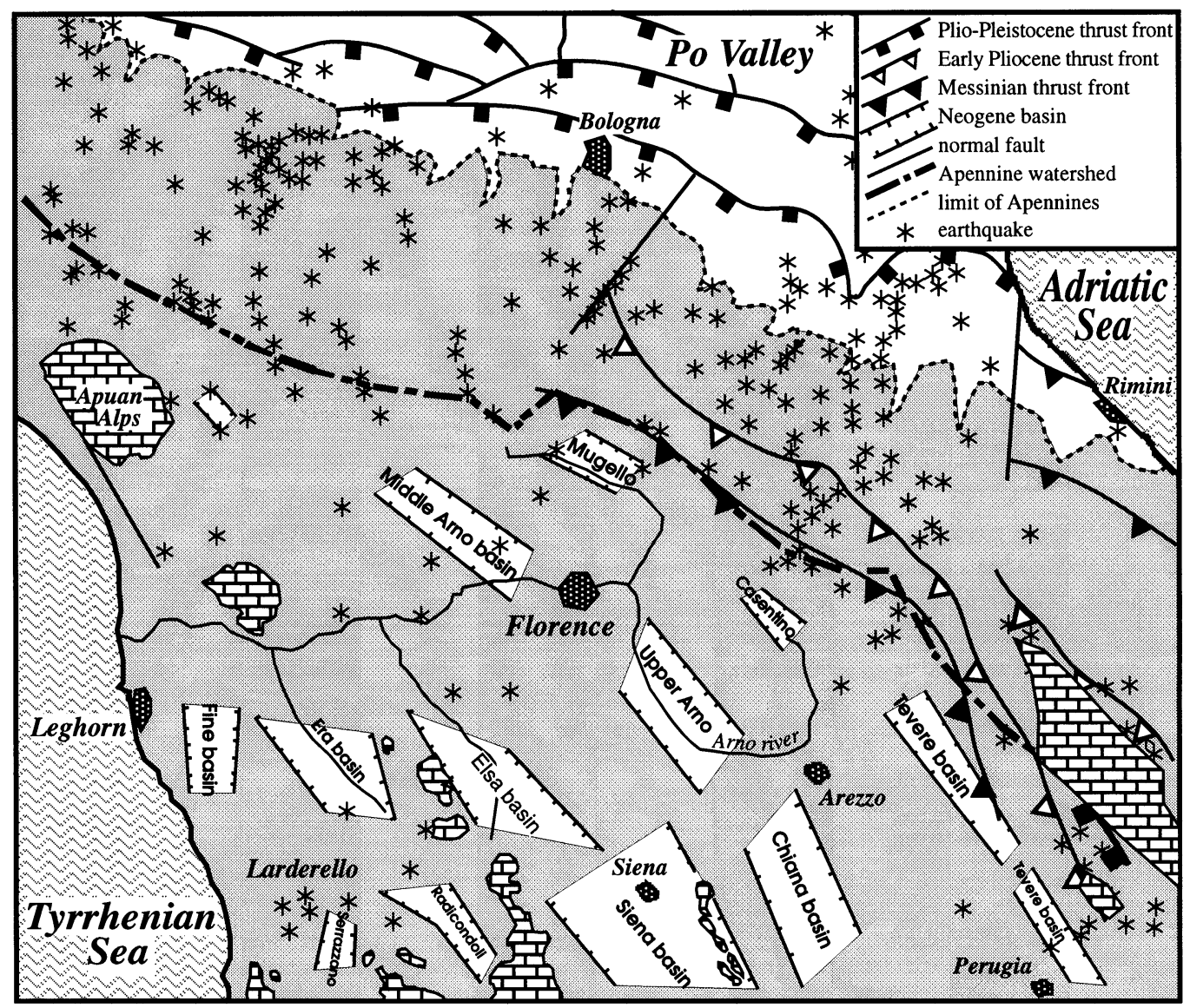

Fig. 14. Map showing the main compressive fronts in the foredeep area and location of earthquakes with magnitude $>2.6$ in the period 1988-1995 [after Frepoli and Amato (1997)].

of earthquakes in the peri-Tyrrhenian belt. Such circulation probably contributes to the removal of stress from potentially active seismic structures, strongly reducing the ratio between high- and lowmagnitude earthquakes. It is noteworthy also to observe that the great majority of earthquakes in the western peri-Tyrrhenian sector (Fig. 14) is concentrated in the Larderello area, with epicenters rarely exceeding $8 \mathrm{~km}$ (Batini et al., 1995). If we consider that: (1) the shallow thermal gradient in some places at Larderello is $>250^{\circ} \mathrm{C} / \mathrm{km}$ (Celati et al., 1976); (2) temperatures $>400^{\circ} \mathrm{C}$ have been measured at $<3000 \mathrm{~m}$ depth (Batini et al., 1983) with an average thermal gradient in the shallow crust $>130^{\circ} \mathrm{C} / \mathrm{km}$; (3) the anomalous heat flow at
Larderello suggests a physical transition from a fragile to ductile regime at $<8 \mathrm{~km}$ in depth (Cameli et al., 1993); and (4) the ${ }^{3} \mathrm{He} /{ }^{4} \mathrm{He}$ isotopic signature of fluids points to the presence of melted mantle-derived magma intruded in the crust, then earthquakes at Larderello can be related to the top of a mantle-contaminated melted crust, representing the main heat source of the Larderello geothermal area.

Crustal contamination of mantle gas is caused by the likely low speed of ascent of the gas from the mantle and the high concentration of $U$ in the crust, which allows ${ }^{4} \mathrm{He}$ accumulation on the way. This may account for a ${ }^{3} \mathrm{He} /{ }^{4} \mathrm{He}$ ratio measured at Larderello well below the typical mantle value. 


\section{Discussion}

Several different types of both natural fluid emission and chemical composition of liquid phases, either associated or not with gas phases, occur in the Northern Apennines. Methane-rich mud volcanoes are located in the compressed part of the Apennine orogene, where mud diapirs are the likely gas carriers. Such rising of mud, gas and associated $\mathrm{Na}-\mathrm{Cl}$ brackish waters is clearly connected to the recent sedimentary cycle of the Po Valley and the Adriatic foredeep deposits. Similar enrichments in $\mathrm{CH}_{4}$ are possibly present in the flysch formations and the underlying OligoMiocene sandstones and Cretaceous shales that discharge $\mathrm{CH}_{4}$ along the Apennine watershed. On the contrary, in the inner part of the Apennines, where extension has caused the intrusion of several magma bodies, e.g. Larderello area, $\mathrm{CO}_{2}$ prevails over $\mathrm{CH}_{4}$. This does not mean that the periTyrrhenian belt is not a $\mathrm{CH}_{4}$-producing area. The Larderello field itself produces about $3000 \mathrm{t} / \mathrm{h}$ of dry steam with approximately $5 \%$ gas, of which about $5 \%$ is $\mathrm{CH}_{4}$, and, thus, discharges about $150 \mathrm{t} /$ day of hydrocarbons into the atmosphere. In the peri-Tyrrhenian sector, methane is simply diluted by the huge quantity of $\mathrm{CO}_{2}$ dispersed in the shallower parts of the crust and produced in several stratified layers in the deeper crust (Minissale et al., 1997a). A similar consideration can be made for the relative total amount of helium discharged at the surface, which is less abundant in the Tyrrhenian sector with respect to the $\mathrm{N}_{2}$ - and $\mathrm{CH}_{4}$-rich vents located $\mathrm{N}$ and $\mathrm{NE}$ of Larderello, simply because of dilution with $\mathrm{CO}_{2}$ (Table 2).

Even from a morphological point of view, the $\mathrm{CO}_{2}$-rich gas vents are different from the $\mathrm{CH}_{4}$ emissions. The former have, indeed, a 'mud basin shape' formed by the alteration of surface soil around the orifice, whereas the latter show the typical mud volcano morphology. This also reflects in the different rate of gas emission in the two areas. Mud volcanoes generally have low gas emission, where the liquid phase and the mud produce a dense mixture slowly bubbling from the orifice, whereas mud basins are related to high gas flux without any expulsion of solid particles. As described by Brown (1990), mud basins, such as the 'Lagoni' ('big ponds') at Larderello, are the surface expression of gas rising at high pressure in a diatreme way. Being diatremes, the structural shape of the crust is affected by the presence of overloaded fluids at depth.

Apart from vertical fluid motion in both 'geothermal' and 'mud volcano' areas, it is also very likely that the Apennines undergo large lateral fluid motion. In orogenic areas such lateral fluid migration has been conceptually summarized by Person and Baumgartner (1995 and references cited therein). In the Apennines, lateral fluid motion from the central backbone to the Tyrrhenian Sea is driven mostly by: (1) the presence of relatively high rainfall affecting the Apennine belt that longitudinally ridges Italy, mostly constituted by permeable Mesozoic limestones and Oligo-Miocene sandstones; (2) hydraulic continuity of the Mesozoic limestones, as described in much of the geological literature of central Italy (e.g. Minissale and Duchi, 1988); (3) high secondary permeability of the Mesozoic limestones, the latter acting as a sink not only for rising deep fluid but also for lateral fluids flowing from the main Apennines.

Both vertical and lateral fluid motions across the northern Apennines as a function of the main hydrogeological units, surface emergence of fluids and underground temperatures are schematized in the block diagram and the SW-NE cross-section across Italy of Fig. 15. The diagram shows the relationship between extension and compression areas, waters and gas compositions in the main hydrogeological units, as well as the surface morphological means of fluid discharge to the surface. The Mesozoic limestones, at least in the periTyrrhenian sector, play a key role in both their buried confined and shallow unconfined conditions in driving fluid motion along preferential subsurface paths. In particular, where limestones are buried under an impermeable caprock made by either the flysch Ligurids or the Neogene material and which are affected by geothermal temperature $\left(>250^{\circ} \mathrm{C}\right.$ as at Larderello), they can be regarded as a gas-producing and a gas-accumulation reservoir. This depends on: (1) sealing phenomena at the boundary of the geothermal systems; (2) 


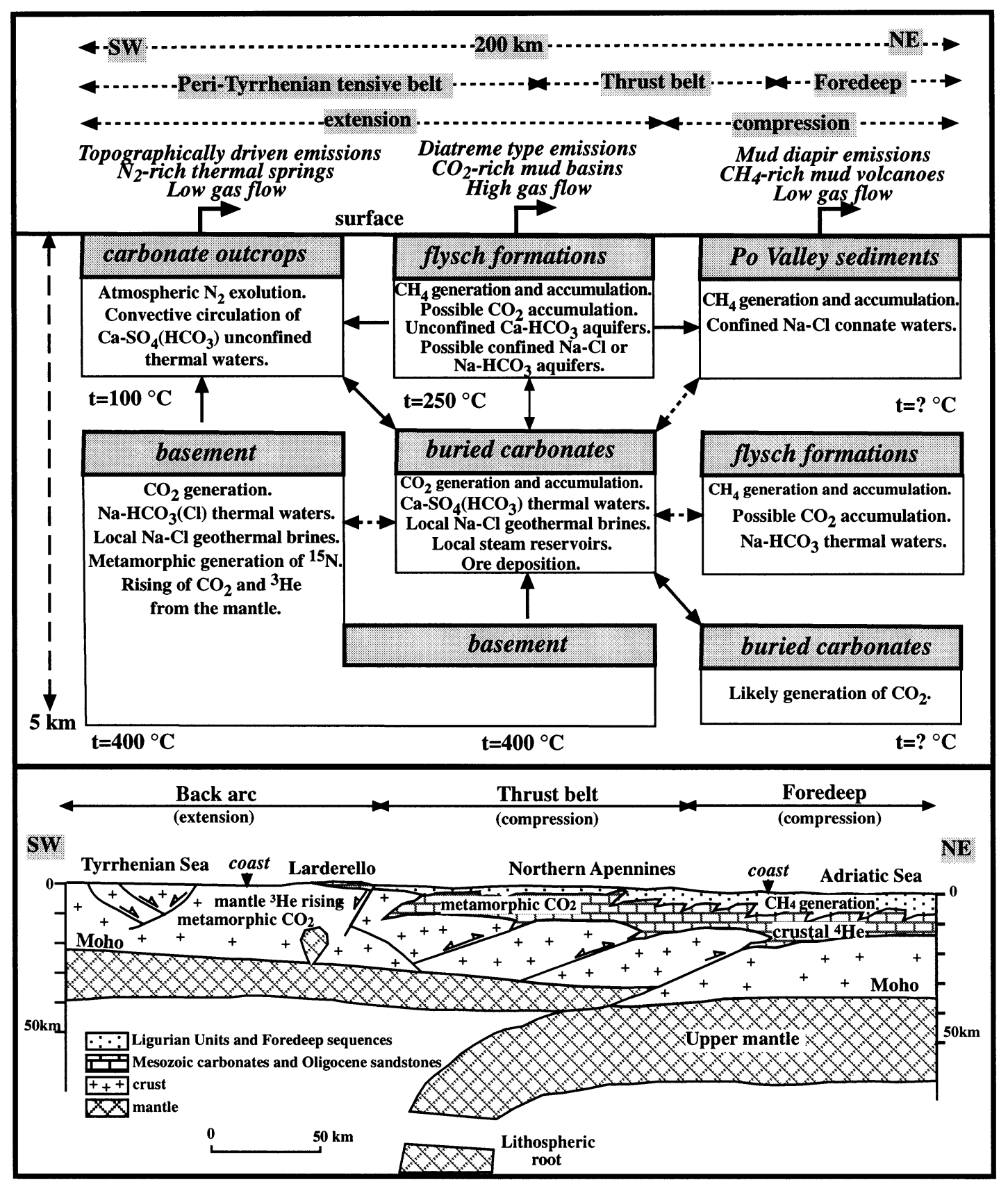

Fig. 15. Block diagram (upper part) and schematic geologic cross-section (lower part) through the northern Apennines. The block diagram summarizes the fluid generation and motion in the main hydrogeological units in the Northern Apennines. Solid lines point to potentially high permeability between tectonic units. Dashed lines suggest low transmissivity for fluids. 
hydraulic continuity inside the carbonate formations between outcrop and buried areas; (3) local fluid overloading in geological structures where the limestones behave as a fluid trap (buried structural top). In such as the latter structural condition, especially where the Mesozoic limestones are not connected to their outcrop areas, ore deposition may occur inside the limestones, and all southern Tuscany hosts several pyrite and $\mathrm{Pb}-\mathrm{Cu}-\mathrm{Zn}$ sulfide deposits.

The foredeep areas are much less affected by fluid motion than the peri-Tyrrhenian sector for several reasons:

(1) a deeper Moho depth, and consequently lower thermal gradients and lower fluid production;

(2) the rising fluid from depth is greatly blocked on its way due to the compressive wave;

(3) the presence of quite thick impermeable formations, such as the flysch units and Neogene sediments;

(4) the absence of shallow formations acting as a sink for fluids, like the Mesozoic limestones do in the peri-Tyrrhenian sector.

Methane is the only fluid discharged at the surface and is likely to be generated at shallow depth.

\section{Concluding remarks}

There seems to be a clear relation between fluid occurrence and morphology, as well as of chemical and isotopic composition, for both waters and gases expelled across an active orogenic system such as the Northern Apennines. Among the many parameters investigated, the main composition of waters and their isotopic signature $\left(\delta^{18} \mathrm{O}\right.$ and $\left.\delta \mathrm{D}\right)$, as well as the $\delta^{13} \mathrm{C}$ in $\mathrm{CO}_{2}$ and $\mathrm{CH}_{4}$ and the ${ }^{3} \mathrm{He} /{ }^{4} \mathrm{He}$ ratio of gases, have proved to be the best parameters to understand their source origin. In particular, the distribution pattern of ${ }^{3} \mathrm{He} /{ }^{4} \mathrm{He}$ ratios seems to suggest the presence of still-degassing mantle-derived magmas in the western periTyrrhenian sector (extension), as well as the shallowness of the structures in the more external areas of the Northern Apennines, still undergoing a strong stress regime (compression).
The comparison between the situation in different active orogenic areas (Toutain and Baubron, 1998 and references cited therein; Kennedy et al., 1997; Minissale et al., 1999a,b) will contribute to a better understanding of globalscale fluid motion triggered by active tectonics.

\section{Acknowledgements}

A.M., O.V. and F.T. are grateful to Professor V. Duchi of the University of Florence for his tuition over many years on hydrogeochemistry and analytical procedures. We also thank W.C. Evans (US Geological Survey, Menlo Park, CA) for $\delta^{15}$ $\mathrm{N}$ measurements and B. Capaccioni (University of Urbino, Italy) for the analysis of light hydrocarbons in gases from mud volcanoes, and the journal referees.

\section{References}

Abbate, E., Bortolotti, V., Passerini, P., Sagri, M., Sestini, G., 1970. Development of the northern Apennines geosyncline. Sediment. Geol. 4, 207-642.

Amato, A., Biella, G., Chiesa, S., De Franco, R., Malignini, L., Minelli, G., Ponziani, F., Vezzoli, F., 1993. TuscaniaPienza seismic refraction profile, geophysical model and geological interpretation. Mem. Descr. Carta Geol. It. 49, 23-36.

Andrews, J.N., 1985. The isotopic composition of radiogenic helium and its use to study groundwater movements in confined aquifers. Chem. Geol. 49, 339-351.

Anelli, L., Gorza, M., Pieri, M., Riva, M., 1994. Subsurface well data in the Northern Apennines (Italy). Mem. Soc. Geol. It. 48, 461-471.

Arrigoni, P., Fico, L., Piovesana, F., Sommaruga, C., 1982. . In; Industria termale e utilizzazione dei fluidi geotermici, l'esempio del progetto Bagno di Romagna. Aquater s.p.a., S. Lorenzo in Campo, Italy, pp. 1-29.

Barnes, I., Irwin, W., White, D., 1978. Global distribution of $\mathrm{CO} 2$ and major zones of seismicity. US Geol. Surv., OpenFile Rep. 78-39.

Batini, F., Bertini, G., Bottai, A., Burgassi, P.D., Cappetti, G., Gianelli, G., Puxeddu, M., 1983. St. Pompeo 2 deep well: a high temperature and high pressure geothermal systems. In: Proceedings of the 3rd International Seminar on European Geothermics Update, Munich, FRG, pp. 341-353.

Batini, F., Fiordelisi, A., Graziano, F., Nafi Toksoz, M., 1995. Earthquake tomography in the Larderello geothermal area. 
In: Proceedings of the 1995 World Geothermics Congress, Florence, Italy, 18-31 May, pp. 817-820.

Bencini, A., Duchi, V., 1981. Studio geochimico su alcune acque di Porretta Terme, Bologna, Italia. Rend. Soc. It. Mineral. Petrol, 38, 1189-1195.

Bencini, A., Duchi, V., Martini, M., 1977. Geochemistry of thermal springs of Tuscany. Chem. Geol. 19, 229-252.

Bencini, A., Duchi, V., Rainero, E., 1979. Indagine geochimica su alcune acque minerali della provincia di Firenze. Rend. Soc. It. Mineral. Petrol. 35, 667-675.

Bertrami, R., Cioni, R., Corazza, E., D’Amore, F., Marini, L., 1985. Carbon monoxide in geothermal gases, reservoir temperature calculations al Larderello (Italy). Geotherm. Resourc. Council Trans. 9, 299-303.

Boccaletti, M., Guazzone, G., 1974. Remnant arcs and marginal basins in the Cenozoic development of the Mediterranean. Nature 252, 18-21.

Boccaletti, M., Sani, F., 1998. Cover thrust reactivations related to internal basement involvement during Neogene-Quaternary evolution of the northern Apennines. Tectonics 17, 112-130.

Boccaletti, M., Cerrina-Ferroni, A., Martinelli, P., Moratti, G., Plesi, G., Sani, F., 1992. Late Miocene-Quaternary compressive events in the Tyrrhenian side of the Northern Apennines. Ann. Tecton. 6, 214-230.

Bonini, M., Moratti, G., Sani, F., 1999. Evolution and depocenter migration in thrust-top basins: inferences from Messinian Velona Basin (Northern Apennines, Italy). Tectonophysics 304, 95-108.

Borgia, G.C., Elmi, C., Ricchiuto, T., 1988. Correlation by genetic properties of the shallow gas seepages in the Emilian Apennine (Northern Italy). Org. Geochem. 13, 319-324.

Brown, K.M., 1990. The nature and hydrologic significance of mud diapirs and diatremes for accretionary systems. J. Geophys. Res. 95, 8969-8982.

Buonasorte, G., Pandeli, E., Fiordelisi, A., 1991. The Alfina 15 well: deep geological data from northern Latium (Torre Alfina geothermal area). Boll. Soc. Geol. It. 110, 823-831.

Calcagnile, G., Panza, G.F., 1979. Crustal and upper mantle structures beneath the Apennine region as inferred from the study of Rayleigh waves. J. Geophys. 45, 319-327.

Calcagnile, G., Panza, G.F., 1982. The main characteristics of the lithosphere-astenosphere system in Italy and surrounding regions. Pure Appl. Geophys. 119, 865-879.

Calore, C., Celati, R., D’Amore, F., Noto, P., 1982. Geochemical evidence of natural recharge in Larderello and Castelnuovo areas. In: Proceedings of the 8th Workshop on Geothermal Reservoir Engineering, Stanford, USA, pp. 323-328.

Cameli, G.M., Dini, I., Liotta, D., 1993. Upper crustal structure of the Larderello geothermal field as a feature of post collisional extensional tectonics (southern Tuscany, Italy). Tectonophysics 224, 413-423.

Carella, R., Verdiani, A., Palmerini, C., Stefani, G.C., 1985. Geothermal activity in Italy: present status and future prospects. Geothermics 14, 247-254.

Casiglia, A., Chandrasekharam, D., Magro, G., Minissale, A.,
Tassi, F., Vaselli, O., 1999. Origin and evolution of crustal fluids from northern peninsular India. Earth. Planet. Sci. Lett.. submitted for publication.

Celati, R., Squarci, P., Stefani, G.C., Taffi, L., 1976. Study of water levels in Larderello region geothermal wells for reconstruction of reservoir pressure trend. Geothermics 5, 183-198.

Chiodini, G., Marini, L., 1998. Hydrothermal gas equilibria: the $\mathrm{H}_{2} \mathrm{O}-\mathrm{H}_{2}-\mathrm{CO}_{2}-\mathrm{CO}-\mathrm{CH}_{4}$ system. Geochim. Cosmochim. Acta 62, 2673-2687.

Chiodini, G., Frondini, F., Ponziani, F., 1995. Deep structures and carbon dioxide degassing in central Italy. Geothermics 24, 81-94.

Conticelli, S., Manetti, P., Menichetti, S., 1992. Mineralogy, geochemistry and Sr-isotopes in orendites from south Tuscany, Italy: constraints on their genesis and evolution. Eur. J. Mineral. 4, 1359-1375.

Costa, E., Pialli, G., Plesi, G., 1998. Foreland basins of the northern Apennines: relationships with passive subduction of the Adriatic lithosphere. Mem. Soc. Geol. It. 52, 595-606.

Craig, H., 1963a. Isotopic variations in meteoric waters. Science 123, 1702-1703.

Craig, H., 1963b. The isotope geochemistry of water and carbon in geothermal areas. In: Tongiorgi, E. (Ed.), Nuclear Geology on Geothermal Areas. Spoleto, Italy, pp. 17-54.

Craig, H., Lupton, J.E., Horibe, Y., 1978. A mantle helium component in circum-Pacific volcanic gases: Hakone, the Marianas and Mt. Lassen. In: Alexander, E.G., Ozima, M. (Eds.), Terrestrial Rare Gases. Central Academic Publishers, Tokyo, Japan, pp. 3-16.

D’Amore, F., Bolognesi, L., 1994. Isotopic evidence for a magmatic contribution to the fluids of the geothermal systems of Larderello and The Geysers. Geothermics 23, 21-32.

D'Amore, F., Nuti, S., 1977. Notes on the chemistry of geothermal gases. Geothermics 6, 39-45.

D’Amore, F., Panichi, C., 1980. Evaluation of deep temperatures of hydrothermal systems by a new gas geothermometer. Geochim. Cosmochim. Acta 44, 549-556.

D’Amore, F., Truesdell, H., 1979. Models for steam chemistry at Larderello and The Geysers. In: Proceedings of the 5th Workshop on Geothermal Reservoir Engineering, Stanford, USA, pp. 283-297.

Davisson, M.L., Presser, T.S., Criss, R.E., 1994. Geochemistry of tectonically expelled fluids from the northern Coast Ranges, Rumsey Hills, California, USA. Geochim. Cosmochim. Acta 58, 1687-1699.

De Rubeis, V., Gasparini, C., Solipaca, A., Tosi, P., 1992. Seismotectonic characterization of Italy using statistical analysis of geophysical variables. J. Geodyn. 16, 103-122.

Duchi, V., Minissale, A., 1995. Distribuzione delle manifestazioni gassose nel settore peritirrenico Tosco-Laziale e loro interazione con gli acquiferi superficiali. Boll. Soc. Geol. It. $114,337-351$.

Duchi, V., Minissale, A., Rossi, R., 1986. Chemistry of thermal springs in the Larderello-Travale geothermal region, southern Tuscany, Italy. Appl. Geochem. 1, 659-667.

Duchi, V., Minissale, A., Prati, F., 1987. Chemical composition 
of thermal springs, cold springs, streams and gas vents in the Mt. Amiata geothermal region (Tuscany, Italy). J. Volcanol. Geotherm. Res. 31, 321-331.

Duchi, V., Minissale, A., Paolieri, M., Prati, F., Valori, A., 1992a. Chemical relationship between discharging fluids in the Siena-Radicofani graben and the deep fluids produced by the geothermal fields of Mt. Amiata, Torre Alfina and Latera (central Italy). Geothermics 21, 401-413.

Duchi, V., Minissale, A., Manganelli, M., 1992b. Chemical composition of natural deep and shallow hydrothermal fluids in the Larderello geothermal field. J. Volcanol. Geotherm. Res. 49, 313-328.

Dunai, T.J., Baur, H., 1995. Helium, neon and argon systematics of the European subcontinental mantle: implications for its geochemical evolution. Geochim. Cosmochim. Acta 59, $2767-2783$.

Francalanci, G., 1956. Contributo per la conoscenza delle manifestazioni termali della Toscana. Atti Soc. Tosc. Sci. Nat. $65,372-432$.

Frepoli, A., Amato, A., 1997. Contemporaneous extension and compression in the Northern Apennines from earthquake fault-plane solutions. Geophys. J. Int. 129, 368-388.

Gatt, J.R., Carmi, I., 1970. Evolution of the isotopic composition of atmospheric waters in the Mediterranean Sea area. J. Geophys. Res. 75, 3032-3048.

Gianelli, G., 1985. On the origin of geothermal $\mathrm{CO}_{2}$ by metamorphic processes. Boll. Soc. Geol. It. 104, 575-584.

Gianelli, G., Calore, C., 1996. Models for the origin of carbon dioxide in the Larderello geothermal field. Boll. Soc. Geol. It. $115,75-84$.

Giggenbach, W.F., 1975. A simple method for the collection and analysis of volcanic gas samples. Bull. Volcanol. 39, 132-145.

Giggenbach, W.F., 1982. Carbon-13 exchange between $\mathrm{CO}_{2}$ and $\mathrm{CH}_{4}$ under geothernal conditions. Geochim. Cosmochim. Acta 46, 159-165.

Giggenbach, W.F., 1991. Chemical techniques in geothermal exploration. In: D'Amore, F. (Ed.), Application of Geochemistry in Geothermal Reservoir Development. UNITAR, Rome, Italy, pp. 119-144.

Giggenbach, W.F., Gonfiantini, R., Jangi, B.L., Truesdell, A.H., 1983. Isotopic and chemical composition of Parbaty Valley geothermal discharges, NW-Himalaya. Geothermics $12,199-222$.

Goguel, J., 1953. Le régime thermique de la eau souterraine. Ann. Mines 10, 1-29.

Griesshaber, E., O’Nions, R.K., Oxburgh, E.R., 1992. Helium and carbon isotope systematics in crustal fluids from the Eifel, the Rhine Graben and Black Forest, F.R.G. Chem. Geol. 99, 213-235.

Hooker, P.J., Bertrami, R., Lombardi, S., O’Nions, R.K., Oxburgh, E.R., 1985. Helium-3 anomalies and crust-mantle interaction in Italy. Geochim. Cosmochim. Acta 49, 2505-2513.

Jenden, P.D., Kaplan, I.R., Poreda, R.J., Craig, H., 1988. Origin of nitrogen-rich natural gases in the California Great
Valley: evidence from helium, carbon and nitrogen isotope ratios. Geochim. Cosmochim. Acta 52, 851-861.

Kennedy, B.M., Kharaka, Y.K., Evans, W.C., Ellwood, A., De Paolo, D.J., Thordsen, J., Ambats, G., Mariner, R.H., 1997. Mantle fluids in the San Andreas fault system, California. Science 278, 1278-1281.

Kissin, I.G., Pakhomov, S.I., 1967. The possibility of carbon dioxide generation at depth at moderately low temperature. Dokl. Akad. Nauk SSSR 174, 451-454.

Kligfield, R., 1979. The orthern Apennines as a collisional orogen. Am. J. Sci. 279, 676-691.

Le Pichon, X., Henry, P., Lallemant, S., 1990. Water flow in the Barbados accretionary complex. J. Geophys. Res. 95, 8945-8967.

Lotti, B., 1910. Geologia della Toscana. Mem. Descrittive della Carta Geologica d'Italia. Tipografia Nazionale, Roma, Italy.

Magro, G., Pennisi, M., 1991. Noble gases and nitrogen: mixing and temporal evolution in the fumarolic fluids of Vulcano, Italy. J. Volcanol. Geotherm. Res. 47, 237-247.

Malinverno, A., Ryan, W.B.F., 1986. Extension in the Tyrrhenian Sea and shortening in the Apennines as a result of arc migration driven by sinking of the lithosphere. Tectonics $5,227-246$.

Mamyrin, B.A., Tolstikhin, I.N., 1984. Helium Isotopes in Nature. Elsevier, Amsterdam, Netherlands. 273 pp.

Manzella, A., Ruggeri, G., Gianelli, G., Puxeddu, M., 1998. Plutonic-geothermal systems of southern Tuscany: a review of the crustal models. Mem. Soc. Geol. It. 52, 283-294.

Marini, L., Chiodini, G., 1994. The role of $\mathrm{CO}_{2}$ in the carbonate-evaporite geothermal systems of Tuscany and Latium, Italy. Acta Volcanol. 5, 95-104.

Martel, D.J., Deak, J.N., Doveni, P., Horvarth, F., O’Nions, R.K., Oxburgh, E.R., Stegena, I., Stute, M., 1989. The leakage rate of mantle helium in the Pannonian Basin. Nature 342, 908-912.

Marty, B., O’Nions, R.K., Oxburgh, E.R., Martel, D., Lombardi, S., 1992. Helium isotopes in Alpine regions. Tectonophysics 206, 71-78.

Martinelli, G., Minissale, A., Verrucchi, C., 1998. Geochemistry of heavily exploited aquifers in the Emilia-Romagna region (Po Valley, northern Italy). Environ. Geol. 36, 195-206.

Mattavelli, L., Novelli, L., 1987. Geochemistry and habitat of natural gases in Italy. Org. Geochem. 13, 1-13.

Mattavelli, L., Ricchiuto, T., Grignani, D., Schoell, M., 1983. Geochemistry and habitat of natural gases in Po basin, northern Italy. Am. Assoc. Pet. Geol. Bull. 67, 2239-2254.

Minissale, A., 1991a. The Larderello geothermal field: a review. Earth-Sci. Rev. 31, 133-151.

Minissale, A., 1991b. Thermal springs in Italy: their relation to recent tectonics. Appl. Geochem. 6, 201-212.

Minissale, A., Duchi, V., 1988. Geothermometry on fluids circulating in a carbonate reservoir in north-central Italy. J. Volcanol. Geotherm. Res. 35, 237-252.

Minissale, A., Duchi, V., Kolios, N., Totaro, G., 1988. Geochemical characteristics of Greek thermal springs. J. Volcanol. Geotherm. Res. 39, 1-16. 
Minissale, A., Evans, W., Magro, G., Vaselli, O., 1997a. Multiple source components in gas manifestations from north-central Italy. Chem. Geol. 142, 175-192.

Minissale, A., Magro, G., Vaselli, O., Verrucchi, C., Perticone, I., 1997b. Geochemistry of water and gas discharges from the Mt. Amiata silicic complex and surrounding areas (central Italy). J. Volcanol. Geotherm. Res. 79, 223-251.

Minissale, A., Magro, G., Tassi, F., Frau, F., Vaselli, O., 1998. The origin of natural gas emissions from Sardinia island, Italy. Geochem. J. 33, 1-12.

Minissale, A., Vaselli, O., Tassi, F., Magro, G., Pezzotta, F., 1999a. Thermal springs around the Quaternary volcanic Ankaratra Mts. (Madagascar). In: Proceedings of the 5th International Symposium on Geochemistry of the Earth Surface, Reykjavik, Iceland, 16-20 August, pp. 523-526.

Minissale, A., Vaselli, O., Tassi, F., Seghedi, I., Magro, G., Ioane, D., 1999b. Fluid sources in orogenic areas, two examples: Northern Apennines and Eastern Carpathians. Europrobe Meeting, 1-6 Oct 1999, Tulcea, Romania. Romanian J. Tectonics Region. Geol. 77, 33.

Mouton, J., 1969. Contribution des méthodes de prospection géothermique et géophysique à l'étude des champes géothermiques de Toscane. Bull. Volcanol. 133, 165-190.

Oliver, J., 1986. Fluids expelled tectonically from orogenic belts: their role in hydrocarbon migration and other geological phenomena. Geology 14, 99-102.

Oliver, J., 1992. The spots and stains of plate tectonics. EarthSci. Rev. 32, 77-106.

O’Nions, R.K., Oxburgh, E.R., 1988. Helium, volatile fluxes and the development of continental crust. Earth Planet. Sci. Lett. 90, 331-347.

Panichi, C., Tongiorgi, E., 1976. Carbon isotopic composition of $\mathrm{CO}_{2}$ from springs fumaroles mofettes and travertines of central and southern Italy: a preliminary prospection method of geothermal areas. In: Proceedings of the 2nd U.N. Symposium on the Development and Use of Geothermal Energy, San Francisco, USA, 20-29 May, 1975, pp. 815-825.

Panichi, C., Celati, R., Noto, P., Squarci, P., Taffi, L., Tongiorgi, E., 1974. Oxygen and hydrogen isotope studies of the Larderello (Italy) geothermal system. In: Isotope Techniques in Groundwater Hydrology, vol. 2, Int. Atomic Energy Agency, SM-182/27. 3-28.

Person, M., Baumgartner, L., 1995. New evidence for long distance fluid migration within the Earth's crust. Rev. Geophys. U.S. Nat. Rep. Int. Union Geodesy Geophys., pp. 1083-1091.
Peccerillo, A., Manetti, P., 1985. The potassium alkaline volcanism of central-southern Italy: a review of the data relevant to petrogenesis and geodynamic significance. Trans. Geol. Soc. S. Afr. 88, 379-394.

Reynolds, S.J., Lister, G.S., 1987. Structural aspects of fluidrock interactions in detachment zones. Geology 15, $362-366$.

Rollison, H., 1993. In: Using Geochemical Data. Longman, London, UK, 352 pp.

Royden, L., Patacca, E., Scandone, P., 1987. Segmentation and configuration of subducted lithosphere in Italy: an important control on thrust-belt and foredeep-basin evolution. Geology 15, 714-717.

Schoell, M., 1988. Multiple origins of methane in the earth. Chem. Geol. 71, 1-10.

Selvaggi, G., Amato, A., 1992. Subcrustal earthquakes in the Northern Apennines (Italy): evidence for a still active subduction? Geophys. Res. Lett. 19, 2127-2130.

Selvaggi, G., Castello, B., Azzara, R., 1997. Spatial distribution of scalar seismic moment release in Italy (1983-1996): seismotectonic implications for the Apennines. Ann. Geofis. 40, 1565-1578.

Serri, G., 1990. Neogene-Quaternary magmatism of the Tyrrhenian region: characterization of the magma sources and geodynamic implications. Mem. Soc. Geol. It. 41, 219-242.

Sestini, G., 1970a. Sedimentation of the late geosynclinal stage. Development of the Northern Apennines Geosyncline. Sediment. Geol. 4, 445-479.

Sestini, G., 1970b. Superheating of geothermal steam. In: Proceedings of 1st U.N. Symposium on the Development and Use of Geothermal Energy, Pisa, Italy. Geothermics 1, 622-648.

Sverjensky, G.H., Garven, G., 1992. Tracing great fluid migrations. Nature 365, 481-482.

Tanelli, G., 1983. Mineralizzazioni metallifere e minerogenesi della Toscana. Mem. Soc. Geol. It. 25, 91-109.

Toutain, J.P., Baubron, J.C., 1998. Gas geochemistry and seismotectonics: a review. Teconophysics 304, 1-27.

Trevisan, L., 1951. Una nuova ipotesi sulla origine di alcune sorgenti termali della Toscana. L'Industria Mineraria 2, $41-42$.

Villa, I., Gianelli, G., Puxeddu, M., Bertini, G., Pandeli, E., 1987. Granitic dykes of $3.8 \mathrm{Ma}$ age from a $3.5 \mathrm{~km}$ deep geothermal wells at Larderello (Italy). Scientific Research and Permanent Education, University of Milan, Abst.

Washington, J.W., Rose, A.W., 1992. Temporal variability of radon concentration in the interstitial gas of soils in Pennsylvania. J. Geophys. Res. 97, 9145-9159. 